\title{
A mineral and cumulate perspective to magma differentiation at Nisyros volcano, Aegean arc
}

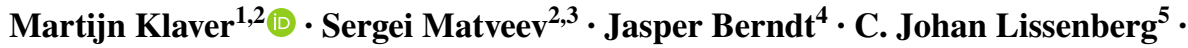 \\ Pieter Z. Vroon ${ }^{2}$
}

Received: 9 March 2017 / Accepted: 16 October 2017 / Published online: 6 November 2017

(C) The Author(s) 2017. This article is an open access publication

\begin{abstract}
Lavas and pyroclastic products of Nisyros volcano (Aegean arc, Greece) host a wide variety of phenocryst and cumulate assemblages that offer a unique window into the earliest stages of magma differentiation. This study presents a detailed petrographic study of lavas, enclaves and cumulates spanning the entire volcanic history of Nisyros to elucidate at which levels in the crust magmas stall and differentiate. We present a new division for the volcanic products into two suites based on field occurrence and petrographic features: a low-porphyricity andesite and a high-porphyricity (rhyo)dacite (HPRD) suite. Cumulate fragments are exclusively found in the HPRD suite and are predominantly derived from upper crustal reservoirs where they crystallised under hydrous conditions from melts that underwent prior differentiation. Rarer cumulate fragments range from (amphibole-)wehrlites to plagioclase-hornblendites
\end{abstract}

Communicated by Othmar Müntener.

Electronic supplementary material The online version of this article (https://doi.org/10.1007/s00410-017-1414-5) contains supplementary material, which is available to authorized users.

Martijn Klaver

martijn.klaver@bristol.ac.uk

1 School of Earth Sciences, University of Bristol, Wills Memorial Building, Queen's Road, Bristol BS8 1RJ, UK

2 Department of Geology and Geochemistry, Vrije Universiteit, De Boelelaan 1085, 1081 HV Amsterdam, The Netherlands

3 GeoLab, Utrecht University, Princetonlaan 8, 3584 CB Utrecht, The Netherlands

4 Institute for Mineralogy, Westfälische Wilhelms-Universität Münster, Corrensstrasse 24, 48149 Münster, Germany

5 School of Earth and Ocean Sciences, Cardiff University, Main Building, Park Place, Cardiff CF10 3AT, UK and these appear to be derived from the lower crust (0.5$0.8 \mathrm{GPa}$ ). The suppressed stability of plagioclase and early saturation of amphibole in these cumulates are indicative of high-pressure crystallisation from primitive hydrous melts $\left(\geq 3 \mathrm{wt} \% \mathrm{H}_{2} \mathrm{O}\right.$ ). Clinopyroxene in these cumulates has $\mathrm{Al}_{2} \mathrm{O}_{3}$ contents up to $9 \mathrm{wt} \%$ due to the absence of crystallising plagioclase, and is subsequently consumed in a peritectic reaction to form primitive, Al-rich amphibole $(\mathrm{Mg} \#>73$, 12-15 wt $\% \mathrm{Al}_{2} \mathrm{O}_{3}$ ). The composition of these peritectic amphiboles is distinct from trace element-enriched interstitial amphibole in shallower cumulates. Phenocryst compositions and assemblages in both suites differ markedly from the cumulates. Phenocrysts, therefore, reflect shallow crystallisation and do not record magma differentiation in the deep arc crust.

Keywords Aegean arc $\cdot$ Nisyros $\cdot$ Arc cumulates $\cdot$ Deep crustal hot zone $\cdot$ Amphibole $\cdot$ Volcanic plumbing system

\section{Introduction}

Arc magmas typically represent mixtures of one or more distinct volatile, melt and mineral components that are not necessarily in equilibrium with each other. A wide variety of macro- and microscopic disequilibrium textures is particularly common in more evolved arc rocks (andesites, dacites and rhyodacites) and includes, amongst others, resorbed or sieve textured phenocrysts, strong compositional zoning, replacement reactions and co-occurrence of olivine and quartz (e.g., Eichelberger 1978; Streck 2008). In addition to textural observations, in situ geochemical analyses of minerals and melt inclusions provide abundant evidence for open-system differentiation of arc rocks (e.g., Davidson et al. 2005; Ginibre et al. 2007). Mineral and melt heterogeneity 
in arc rocks implies that any bulk rock analysis will provide an average composition of multiple geochemically distinct components and inherently obscures a major part of the variation and complexity of a sample (e.g., Reubi and Blundy 2009). In contrast, the composition and textural relationships of mineral phases in arc magmas provide a wealth of information that can be used to investigate petrogenetic processes (e.g., Davidson et al. 2005).

There exists, however, a common mismatch between observed phenocrysts in extrusive products and cumulate assemblages that are inferred from whole rock geochemical trends (e.g., Arculus and Wills 1980; Annen et al. 2006). For example, the important role of amphibole in the evolution of arc magmas, as deduced from lava trace element compositions, is at odds with the common absence of amphibole phenocrysts (e.g., Davidson et al. 2007). It is increasingly recognised that arc magmas can undergo significant modification at the base of the arc crust without leaving a clear trace in their crystal record (e.g., Annen et al. 2006), which is supported by extensive evidence for cumulate-melt reactions in exposed arc root complexes (e.g., Jagoutz et al. 2007; Dessimoz et al. 2012; Bouilhol et al. 2015). Hence, there has been renewed interest in the use of cumulate suites to constrain differentiation processes at different levels in the arc crust (e.g., Tollan et al. 2012; Smith 2014; Stamper et al. 2014; Cooper et al. 2016). In particular, arc cumulates have the potential to record the first stages of magma differentiation that are rarely preserved in the erupted lavas.

We have undertaken a detailed petrographic study of Nisyros volcano, the easternmost volcanic centre of the Aegean arc (Greece), to further the understanding of its magmatic plumbing system and the differentiation of arc magmas in general. Nisyros is particularly well suited for such a study as it has erupted basaltic andesites to rhyodacites with a wide variety of mineral contents and textures over a $<160$ kyr period (e.g., Wyers and Barton 1989; Francalanci et al. 1995; Vanderkluysen et al. 2005a). Moreover, abundant mafic inclusions are present in the Nisyros volcanic products, ranging from quenched enclaves to cumulate fragments. Cumulates vary from microcumulates, consisting of 5-50 crystals within a single thin section, to coarse plagioclase-hornblendite cumulate blocks. Earlier petrographic studies of Nisyros have provided representative mineral chemistry data (Di Paola 1974; Wyers and Barton 1989; Seymour and Vlassopoulos 1992) or were restricted to selected volcanic units (Spandler et al. 2012; Braschi et al. 2014; Zouzias and St Seymour 2014). We expand on these studies and aim to provide a more comprehensive overview of the subaerial volcanic history of Nisyros. In addition, we provide the first detailed petrographic study of (micro)cumulate fragments from Nisyros and evaluate the insights they can provide into the structure of its plumbing system. Of particular interest are the hornblende-gabbro and hornblende-wehrlite cumulates that are potentially derived from the lower arc crust and hence offer a unique opportunity to study cumulate-melt reactions that drive the differentiation of calc-alkaline arc magmas.

\section{Geological setting}

Nisyros is the easternmost volcanic centre of the Aegean arc, which has formed in response to the northward subduction of the African plate underneath the Turkish-Aegean microplate. Volcanism in the eastern section of the arc started with the emplacement of dacitic to rhyolitic domes on Kos from ca. 2.7-0.5 Ma (Pe-Piper and Moulton 2008) and culminated in the large explosive eruption that deposited the Kos Plateau Tuff at $161 \pm 1 \mathrm{ka}$ (Smith et al. 1996; Bachmann et al. 2007). The entirely volcanic island of Nisyros is situated ca. $20 \mathrm{~km}$ to the south of Kos and has a diameter of ca. $8 \mathrm{~km}$ with a central caldera with a diameter of ca. $4 \mathrm{~km}$ (Fig. 1). The subaerial volcanic products of Nisyros are inferred to be younger than $161 \mathrm{ka}$ as the Kos Plateau Tuff was found immediately overlying the non-volcanic basement in drill cores in Nisyros' caldera (Volentik et al. 2005a) and references therein). A short summary of the eruptive history of Nisyros is given here, following the detailed account provided by Vanderkluysen et al. (2005b) and using the classification and abbreviations (in capital letters, e.g., EMB, LF7) of the volcanic units as presented by Volentik et al. (2005b).

The oldest volcanic rocks on Nisyros are the Holaki pillow lavas and hyaloclastites (unit HO), which possibly predate the KPT eruption (Keller 1971). Subaerial activity started with the construction of a small stratocone composed of basaltic andesitic to dacitic lava flows (LF1-LF6) and pyroclastic deposits (e.g., MS) that are exposed in the caldera wall. The presence of intercalated lacustrine sediment deposits suggests that small caldera collapses were followed by periods of volcanic quiescence. The subsequent phase of activity was characterised by the eruption of lava flows and explosive events (LF7, PA, LF8, XO) from multiple different mono- and polygenetic eccentric vents, including the Lies tuff cone on the eastern side of the island. Following these paroxysmal events, the style of volcanism on Nisyros underwent a gradual change from effusive and mildly explosive activity to the emplacement of (rhyo)dacitic domes and lava flows and larger Plinian eruptions. These porphyritic (rhyo)dacites are characterised by the conspicuous presence of mafic enclaves with a large range in phenocryst compositions and disequilibrium textures, which are indicative of magma mingling (Braschi et al. 2012, 2014; Zouzias and St Seymour 2014). Lava flow 7 (LF7), underlying the Lies tuff cone, is the oldest studied enclave-bearing porphyritic dacite, followed by the Emborio domes (EMB) and the calderaforming Lower and Upper Pumice eruptions (LP and UP, respectively; Limburg and Varekamp 1991; Vanderkluysen 


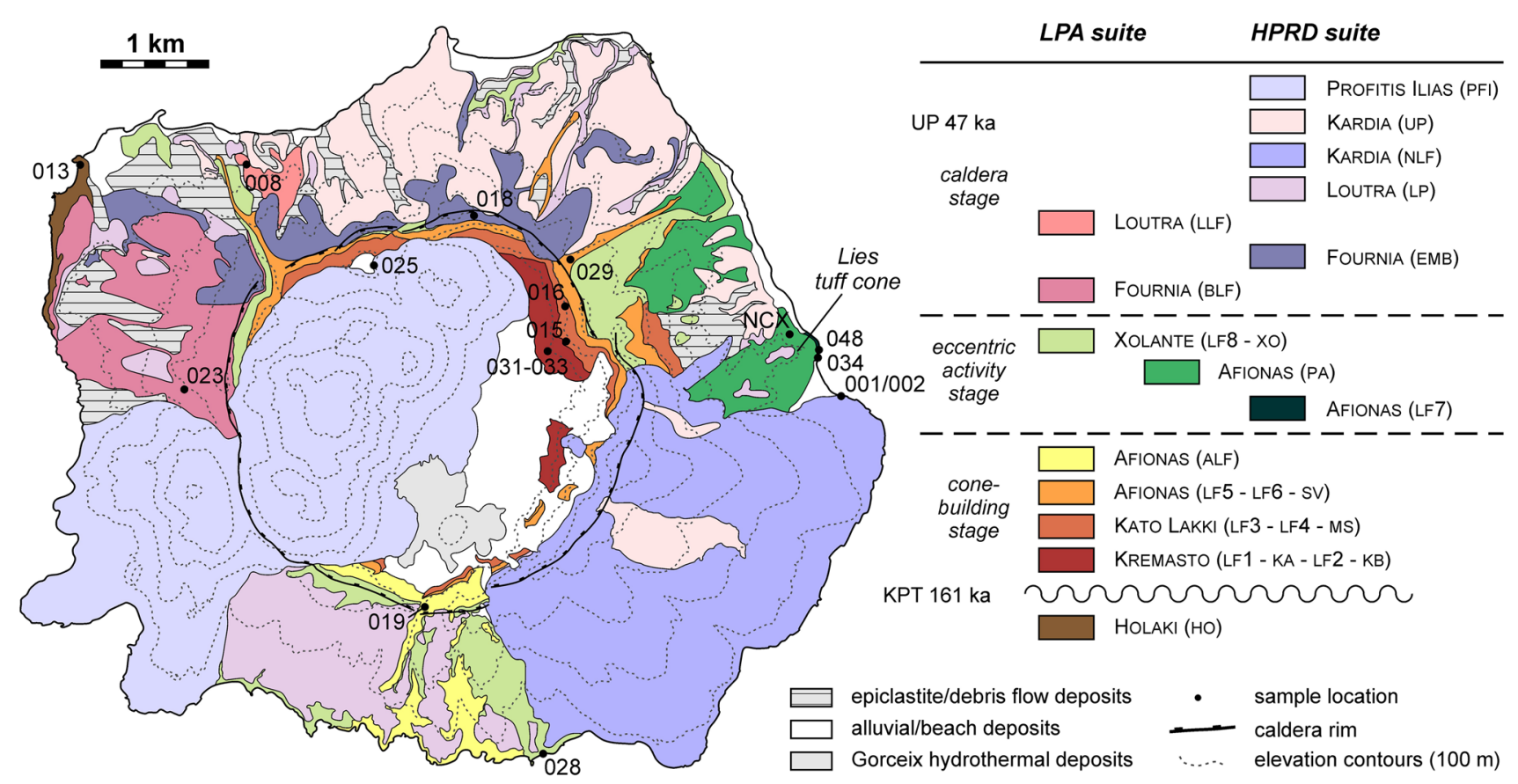

Fig. 1 Geological map of Nisyros, modified after Volentik et al. (2005b). The stratigraphy has been divided into two suites (LPA lowporphyricity andesites, and $H P R D$ high-porphyricity (rhyo)dacites); see text for further discussion. Sampling localities are indicated. Unit

et al. 2005b; Longchamp et al. 2011). The latter are separated by the emplacement of a ca. $1 \mathrm{~km}^{3}$ rhyodacitic, highly viscous block lava flow that covers the southeast of Nisyros: the Nikia flow (NLF; Volentik et al. 2005a). After the eruption of the Upper Pumice, the newly formed caldera was partly filled by the emplacement of six dacitic domes (the Profitis Ilias domes; PFI) that comprise up to 20 vol $\%$ of basaltic-andesitic enclaves.

\section{Analytical methods}

The volcanic deposits that are analysed in this study were sampled on the basis of the geological map of Volentik et al. (2005b) and the volcanic units defined therein, with the aim to cover most of the volcanic history. Whole rock major element compositions of the samples were determined by X-ray fluorescence spectroscopy (XRF) on fused glass beads. LOI was determined by igniting sample powders for $1 \mathrm{~h}$ at $1000{ }^{\circ} \mathrm{C}$. Fused glass beads were made by mixing ignited sample material with $\mathrm{Li}_{2} \mathrm{~B}_{4} \mathrm{O}_{7} / \mathrm{LiBO}_{2}$ (1:4 dilution) and measured on a Panalytical MagixPro XRF instrument at Vrije Universiteit Amsterdam. Results are expressed on a volatile-free basis with $\mathrm{Fe}$ as total ferrous iron $\left(\mathrm{FeO}^{*}\right)$. Mineral compositions were measured on carbon-coated polished sections by wavelength dispersive electron microprobe (EMP) using a JEOL JXA-8800 M at the Vrije Universiteit Amsterdam and a JEOL JXA-8530F at the University of
PA comprises pyroclastic deposits with rapid switching between layers with HPRD and LPA affinity and is thus transitional between the two suites

Bristol. Operating conditions were similar for the two instruments. The EMP was operated at an acceleration voltage of $15-20 \mathrm{kV}$ and a beam intensity of 20-25 nA. A focussed beam was used for the analysis of olivine, pyroxene and amphibole while plagioclase was analysed with a spot size of $10 \mu \mathrm{m}$. All analyses were matrix-corrected using the ZAF (VU) or $\varphi(r Z)$ method (Bristol) and calibrated against natural and synthetic mineral standards. Accuracy of the calibration was tested by regular analysis of mineral standards and calibration was accepted in case the standard values were reproduced at least within 1\% (RSD) for each element. Mineral compositions were checked for stoichiometry by normalising to four atoms per formula unit (apfu) $\mathrm{O}$ for olivine, six apfu $\mathrm{O}$ for pyroxene and eight apfu $\mathrm{O}$ for plagioclase. Amphibole was classified on the basis of 13 apfu O (Leake et al. 1997). Analyses were excluded if the sum of cations was $<99.5$ or $>100.5 \%$ than the stoichiometric value $(<1 \%$ of the analyses).

Mineral trace element concentrations of selected samples were determined by laser-ablation inductively coupled plasma mass spectrometry (LA-ICPMS) at the Westfälische Wilhems-Universität Münster. Ablation was achieved with a 193-nm excimer laser-ablation system (Analyte G2, Photon Machines) connected to a ThermoFisher Element 2 mass spectrometer. The repetition rate of the laser was set to $5-10 \mathrm{~Hz}$ with an energy density of $\sim 4 \mathrm{~J} / \mathrm{cm}^{2}$ and a spot size of $35 \mu \mathrm{m}$. Optimisation of the system was aimed at 
maximum sensitivity for ${ }^{139} \mathrm{La}$ and ${ }^{232} \mathrm{Th}$ on the NIST 612 reference material while keeping oxide production below $0.1 \%\left({ }^{232} \mathrm{Th}^{16} \mathrm{O} /{ }^{232} \mathrm{Th}\right)$. A single measurement lasted $60 \mathrm{~s}$ including $20 \mathrm{~s}$ background measurements. GLITTER software (Griffin et al. 2008) was used to calculate concentrations for the measured elements with NIST 612 reference material as an external standard and internal standardisation to ${ }^{43} \mathrm{Ca}$. Laser-ablation spots were put on top of EMP spots as much as possible and hence Ca contents obtained by EMP could be used for normalisation. Plagioclase is characterised by significant heterogeneity in Ca content on a scale much finer than the LA spot size and these variations would introduce a significant uncertainty in the internal normalisation. Based on the stoichiometry of feldspar, we used measured $\mathrm{Si} / \mathrm{Ca}$ to derive an integrated $\mathrm{Ca}$ and anorthite content for each LA spot and used this Ca content to obtain corrected trace element concentrations (see supplementary material). Glass reference material BCR-2G was used to monitor precision and accuracy, and reproducibility was better than $10 \%$ (2 RSD) for elements of interest (see supplementary material).

\section{Results}

\section{Petrography}

Two suites of volcanic rocks can be identified on Nisyros that are easily distinguished on the basis of petrography and field relationships. The main distinguishing feature is the clear evidence for magma mingling, such as the abundance of magmatic enclaves and disequilibrium textures, in the first suite while the second suite is characterised by an on average lower crystal content and lack of macroscopic evidence for mingling. The two suites have been somewhat haphazardly classified as the "pre-" and "post-caldera" magmatic series by Buettner et al. (2005) and Zellmer and Turner (2007). This terminology is, however, not very exact as there have been multiple caldera-forming events on Nisyros. In addition, we have identified multiple units that predate the last caldera collapse as part the magma-mingling suite, including lava flow 7 (LF7), the Emborio domes (EMB) and the Nikia flow (NLF). Hence, we prefer to classify the two suites based on their petrography and field occurrence in a lowporphyricity andesite (LPA) suite and high-porphyricity (rhyo)dacite (HPRD) suite (Fig. 1). The LPA suite comprises most of the oldest volcanic units emplaced during the early cone-building stage, including the lower part of the succession of lava flows that is exposed in the caldera wall, and is dominated by lava flows and mildly explosive pyroclastic and scoria deposits. After the episode of violent eccentric activity following the initial cone building stage, the enclave-bearing HPRD suite became the dominant magmatic series. HPRD units occur as domes (EMB, PFI), pyroclastic deposits related to explosive eruptions (LP and UP) and viscous block lava flows (LF7, NLF).

\section{LPA suite}

The low-porphyricity andesite suite comprises basalticandesites, andesites and rare dacites. The majority of the LPA units form a group of petrographically homogeneous andesites. These vesicular ( $0-70$ vol\% vesicles), low-porphyricity andesites ( $0-10$ vol\% phenocrysts) have a glassy to fine-grained, plagioclase-dominated microlite groundmass with phenocrysts of plagioclase, olivine, clinopyroxene, $\mathrm{Fe}-\mathrm{Ti}$-oxides and rare orthopyroxene (Fig. 2). Plagioclase is generally euhedral but displays a wide variety of zoning patterns. Rim compositions vary largely between and within samples in the range $\mathrm{An}_{57-81}$ and samples often contain both normally and reversely zoned plagioclase crystals. Crystals with complex zoning are typically more subhedral and contain sieve textured cores up to $\mathrm{An}_{88}$. Olivine is the most common phenocryst phase after plagioclase, is subto euhedral and displays normal zoning from homogeneous core compositions $\left(\mathrm{Fo}_{69-74}\right)$ to variable, more Fe-rich rims. Sub- to euhedral clinopyroxene crystals are in general normally zoned from Mg\# 85 cores to Mg\# 69-76 rims, but can also show reverse zoning to $\mathrm{Mg} \# 80$ rims.

Dacites of the LPA suite are restricted to only two samples (LF1 and a dyke therein) and contain an equilibrium mineral assemblage of plagioclase, amphibole, Fe-Ti-oxides and orthopyroxene (Fig. 2c). Apart from opacite reaction rims related to decompression, amphibole phenocrysts are euhedral and in apparent equilibrium with the matrix. Plagioclase is generally euhedral and shows normal zoning with a limited range of $\mathrm{An}_{40-45}$, but a few crystals have resorbed, sieve textured cores. Orthopyroxene is sub- to euhedral and homogeneous at $\mathrm{Mg} \#$ 60-62, and Fe-Ti-oxides are more abundant than in the andesites $(\sim 2$ and $\sim 1 \mathrm{vol} \%$, respectively). Unit ALF represents a low-porphyricity rhyodacite that is hence treated here as part of the LPA suite. Basaltic andesites in the LPA suite are different from the andesites in that they generally have a higher crystal content (10-40 vol\%; Francalanci et al. 1995). Clinopyroxene is the dominant $\mathrm{Fe}-\mathrm{Mg}$ phase and occurs as euhedral, up to $5 \mathrm{~mm}$ large normally zoned crystals in LF4 and the Holaki pillow lavas (HO). Core domains of these large crystals are the most magnesian on Nisyros (Mg\# 91). Clinopyroxene in HO commonly has resorbed, sieve textured cores with normal zonation from $\mathrm{Mg} \# 80$ to 75 with euhedral rims that range from $\mathrm{Mg} \# 85$ to 80 , as also described by Spandler et al. (2012). The basaltic andesites either contain olivine, zoned from $\mathrm{Fo}_{81-83}$ cores to $\mathrm{Fo}_{70}$ rims in the Aghia Basilei lava flows (BLF), or orthopyroxene with Mg\# 78-80 in 


\section{LPA suite}

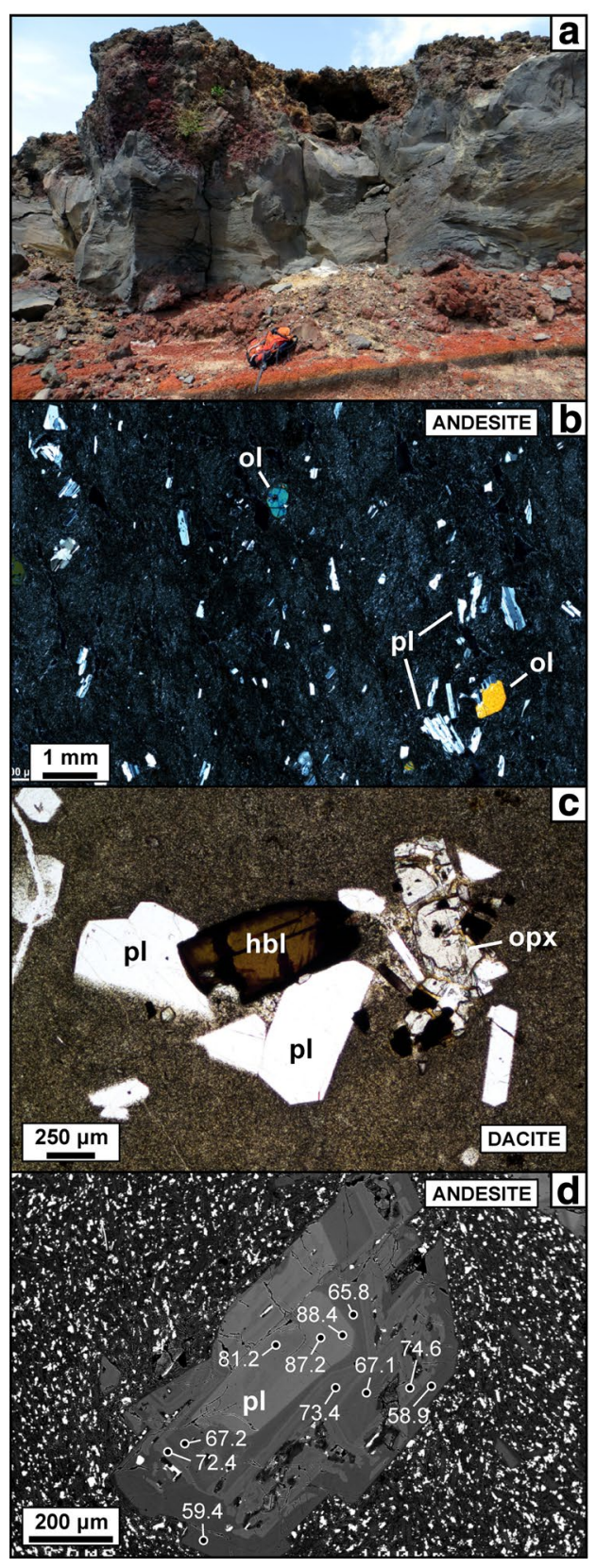

Fig. 2 Petrographic features of the volcanic rocks of Nisyros. Photomicrographs are in plain-polarised light unless otherwise stated; a LPA suite Lava Flow 8 (unit LF8) and associated scoria deposits (XO) that were deposited during the eccentric activity stage at Aghia Irini; backpack $(\sim 60 \mathrm{~cm})$ for scale; $\mathbf{b}$ typical texture of a low-porphyricity andesite (sample AAN-029-LF6), in cross-polarised light (XPL): very fine microlite to glassy groundmass and low crystal content with sub- to euhedral plagioclase, olivine and clinopyroxene (not in this photo) phenocrysts. Note the faint flow banding and alignment of plagioclase phenocrysts; $\mathbf{c}$ glomeroporphyritic aggregate of euhedral, unzoned hornblende, plagioclase, orthopyroxene and $\mathrm{Fe}-\mathrm{Ti}$-oxides in a very fine grained groundmass: the typical texture of LPA dacites (AAN-031-LF1); d complexly zoned plagioclase crystal in an LPA andesite; spots show An\% (AAN-015-LF3);
HPRD suite

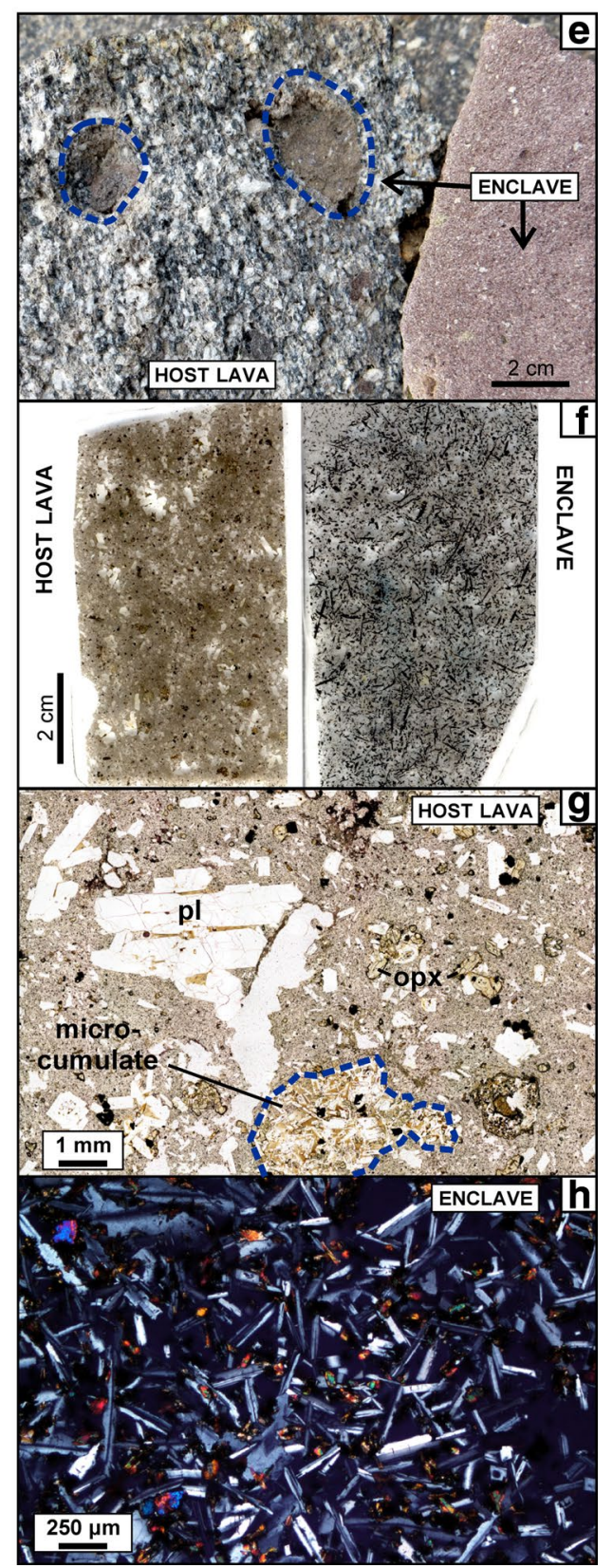

e host rock and enclave fragment of the Profitis Ilias domes (PFI), an HPRD enclave-bearing rhyodacite. Note the two smaller enclaves in the host rock fragment; f HPRD suite host lava (AAN-034-LF7) and enclave (AAN-018b-EMB) thick sections $(\sim 200 \mu \mathrm{m})$ that display the high crystal content of the HPRD lavas and acicular amphibole in the quenched enclave; $\mathbf{g}$ typical HPRD suite mineral association with euhedral plagioclase, Fe-Ti-oxides and coarse, euhedral orthopyroxene (AAN-034-LF7). Note the presence of a plagioclase-clinopyroxene-olivine microcumulate and trapped interstitial glass between the large plagioclase crystals; $\mathbf{h}$ texture of a quenched enclave (in XPL) with acicular plagioclase crystals, fine-grained amphibole (reddish-brown) and a few olivine and clinopyroxene phenocrysts (AAN025b-PFI) 
LF4 and HO, but the two minerals have not been observed together in one thin section. Fe-Ti-oxides are very rare in the basaltic andesites.

\section{HPRD suite}

The high-porphyricity dacites and rhyodacites are distinguished from the LPA suite by their higher crystal content (20-40 vol\%) and more felsic composition ( $>64 \mathrm{wt} \% \mathrm{SiO}_{2}$ ). The most striking macroscopic feature of the HPRD suite is the abundance of enclaves and cumulate fragments in these units. Dacites cannot be easily distinguished from rhyodacites on the basis of petrography as they have a common texture of coarse plagioclase (up to $1 \mathrm{~cm}$ ), orthopyroxene, Fe-Ti-oxides and subordinate clinopyroxene in a plagioclase-dominated microlite groundmass (Fig. 2). Plagioclase is the most abundant phenocryst phase (10-35 vol\%) and can be roughly grouped into euhedral equilibrium plagioclase and sub- to anhedral disequilibrium plagioclase. Braschi et al. (2014) recognise five distinct plagioclase types in the Profitis Ilias domes (PFI) on the basis of crystal habit, zoning patterns and presence of sieve textured cores and/ or dusty rims. These authors relate the wide variety in plagioclase textures to magma mingling and the transfer of plagioclase crystals from the host rock to the enclaves and vice versa. Compared to the other HPRD units, plagioclase crystals in the PFI domes are more anhedral and disequilibrium textures are significantly more common. Euhedral, oscillatory zoned plagioclase is dominant in LF7, the Emborio domes (EMB) and the Nikia flow (NLF). Typical plagioclase rim compositions in the HPRD dacites (LF7, EMB) are $\mathrm{An}_{40-52}$, compared to ca. $\mathrm{An}_{30}$ in the rhyodacites (NLF, PFI); core compositions and zoning patterns are variable, with compositions ranging up to $\mathrm{An}_{90}$. Orthopyroxene crystals are generally euhedral, commonly associated with Fe-Tioxides and homogeneous at $\mathrm{Mg \#} \mathrm{58-63.} \mathrm{Clinopyroxene} \mathrm{is}$ subordinate to orthopyroxene in the HPRD suite and occurs as an- to euhedral isolated grains with $\mathrm{Mg \#}$ between 67 and 73 , sometimes with a reaction rim. Amphibole has not been found as phenocrysts and occurs exclusively in disaggregated fragments of enclaves.

\section{Enclaves and cumulates in the HPRD suite}

Mafic inclusions in the HPRD suite display a large textural and mineralogical variation and can be divided into nearly holocrystalline plutonic xenoliths and quenched enclaves. The latter commonly have chilled margins, contain up to $15 \mathrm{vol} \%$ vesicles and display a fine-grained texture of acicular, occasionally spherulitic, amphibole (up to $1 \mathrm{~cm}$ in length) and plagioclase with groundmass $\mathrm{Fe}-\mathrm{Ti}$-oxides and diktytaxitic voids (Fig. 2). This texture indicates that the enclaves formed in response to quench crystallisation of a hot, mafic melt injected into a cooler reservoir (e.g., Bacon 1986). Enclaves are generally rounded in EMB and LF7 but can be more irregular in PFI and range in size from $<1 \mathrm{~mm}$ to $50 \mathrm{~cm}$ (Fig. 2e). Of the studied units, the largest enclaves and highest abundance are found in the PFI domes (see Braschi et al. 2012 for a detailed description). Crystals in the enclaves that appear to predate the quench crystallisation are referred to as phenocrysts. The PFI enclaves contain less than 5 vol\% phenocrysts that predominantly comprise dusty, sieve textured plagioclase and minor olivine and clinopyroxene. Enclaves in LF7, however, contain reasonably abundant clinopyroxene, olivine and calcic plagioclase phenocrysts (in total 20-30 vol\%) set in a groundmass of acicular amphibole, plagioclase and orthopyroxene (Fig. 3c). Plagioclase phenocrysts are strongly zoned from $\mathrm{An}_{87-91}$ cores to $\mathrm{An}_{58-63}$ rims. Olivine also displays normal zoning from $\mathrm{Fo}_{80}$ cores to $\mathrm{Fo}_{67}$ rims. Orthopyroxene occurs both as acicular crystals in vesicles as well as in complex, vermicular intergrowths with plagioclase.

On the other side of the mafic inclusion spectrum are plutonic xenoliths. Textural and chemical evidence indicates that minerals in these xenoliths formed through fractional crystallisation and that their bulk composition forms a subtractive assemblage that is unlike any of the whole rock compositions found on Nisyros. Hence, these plutonic xenoliths are referred to as cumulates following the classification of Irvine (1982), which is applicable irrespective of the presence of intercumulus crystals or melt. Cumulates vary in size from $>50$ to $<0.5 \mathrm{~mm}$ and occur both as discrete nodules found in pyroclastic deposits (Lies tuff cone, Lower Pumice) and as microcumulates. The latter are defined as clusters of 5-50 crystals in HPRD samples that are only visible in thin section. Plagioclase, clinopyroxene and olivine are the dominant mineral phases, together with subordinate amphibole, $\mathrm{Fe}-\mathrm{Ti}$-oxides and trapped interstitial melt. Microcumulates typically show strong disequilibrium textures such as normal zoning and orthopyroxene mantles around olivine when hosted in a (rhyo)dacitic melt (Fig. 3d). Crystal-rich ( 70 vol\%) plagioclase-hornblendite cumulates are restricted to the Nikia flow (NLF). These cumulate blocks are rounded and characterised by a general absence of chilled margins, but sometimes display a vesicle-rich halo around the enclave in the rhyodacitic host rock. Euhedral, coarse (up to $1 \mathrm{~cm}$ ) amphibole constitutes $25-30 \mathrm{vol} \%$ of the minerals and lath-shaped plagioclase, clinopyroxene ( $0-5 \mathrm{vol} \%)$, $\mathrm{Fe}-\mathrm{Ti}$-oxides, interstitial glass and ca. $10 \%$ vesicles fill up the space between the coarse amphibole grains. Amphibole is zoned but lacks an opacite rim and is found to be growing at the expense of clinopyroxene (Fig. 3f). The different types of cumulates (Type 1-3) are described in detail in the discussion. 

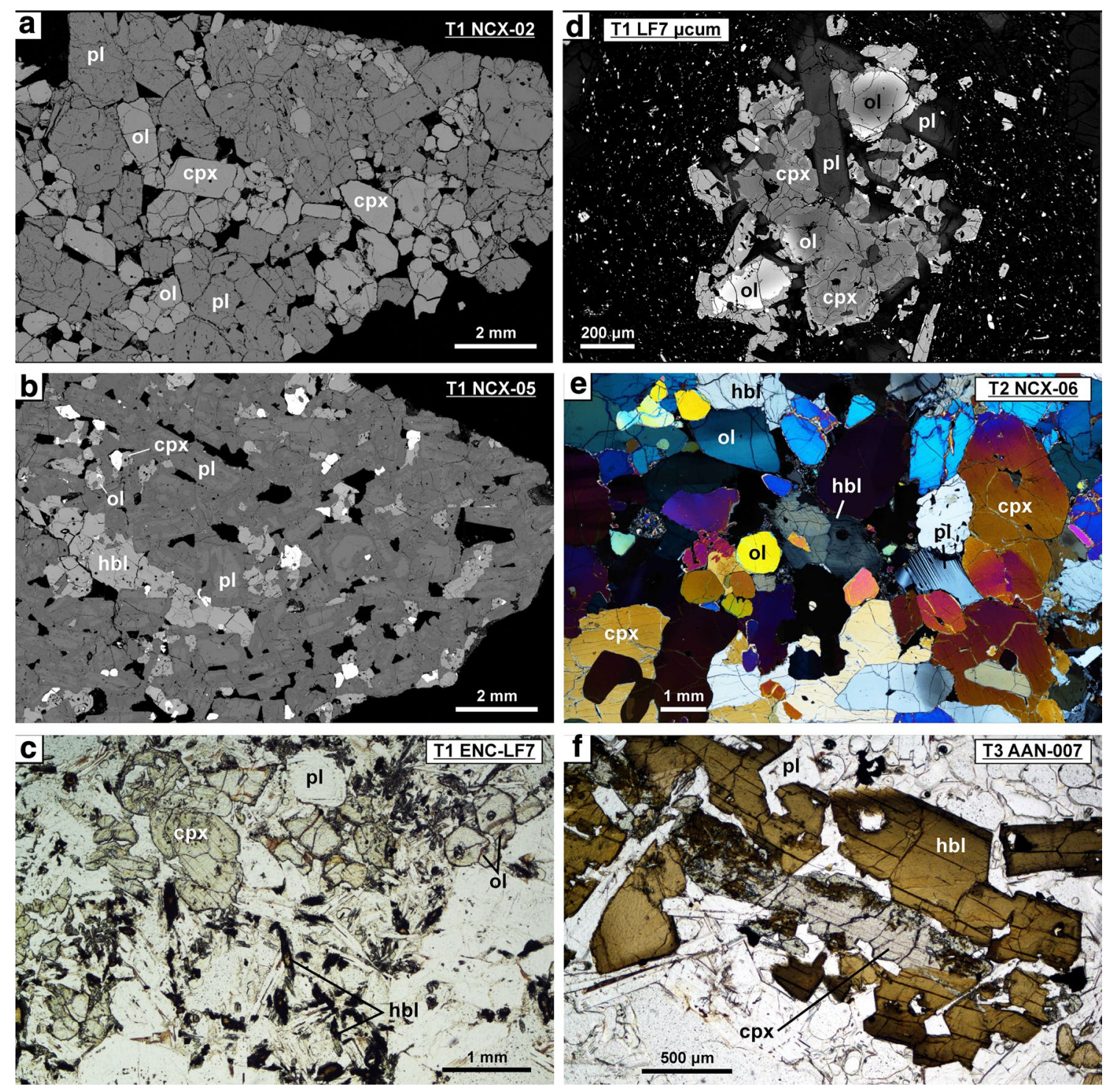

Fig. 3 Petrography of Nisyros cumulates. Cumulates are grouped in Types 1-3 (T1-3) as discussed in the text; a Type 1 holocrystalline plagioclase (pl), clinopyroxene (cpx) and olivine (ol) cumulate with equilibrated grain boundaries. All phases are homogeneous and lack compositional zoning; b similar cumulate as a, but with magnetite (white phases), amphibole (hbl) and quenched interstitial melt. Plagioclase is lath shaped and shows strong compositional bimodality with resorbed $\mathrm{An}_{80-90}$ cores and $\mathrm{An}_{50-65}$ rims; c clinopyroxene, olivine and plagioclase phenocrysts in an LF7 enclave predate quench

\section{Whole rock composition}

Major element data for the studied samples overlap with previously reported data for Nisyros (Di Paola 1974; Wyers and Barton 1989; Seymour and Vlassopoulos 1992; Francalanci et al. 1995; Buettner et al. 2005; Vanderkluysen et al. 2005a; Zellmer and Turner 2007; Braschi et al. 2012; Spandler et al. 2012). Nisyros lavas range from medium- $\mathrm{K}$ basaltic andesites to high- $\mathrm{K}$ rhyodacites

crystallisation of acicular amphibole and plagioclase; $\mathbf{d}$ microcumulate in LF7 that shows pronounced disequilibrium with the host melt, indicated by strong zoning and reaction-replacement of olivine with orthopyroxene; e Type 2 hornblende-wehrlite cumulate with euhedral olivine, poikilitic clinopyroxene and late-stage equilibrium amphibole (in XPL). A single plagioclase crystal is present in the otherwise plagioclase-free sample; f Type 3 amphibole-plagioclase cumulate with amphibole replacing clinopyroxene

(Fig. 4). The samples show typical fractional crystallisation trends with decreasing $\mathrm{Al}_{2} \mathrm{O}_{3}, \mathrm{CaO}, \mathrm{MgO}$ and $\mathrm{Mg} \#$ (molar $\mathrm{Mg} /[\mathrm{Mg}+\mathrm{Fe}]$ ) and increasing $\mathrm{Na}_{2} \mathrm{O}$ and $\mathrm{K}_{2} \mathrm{O}$ with $\mathrm{SiO}_{2}$ content. Basaltic andesites in the LPA suite have $\mathrm{Mg} \#$ up to 68 while major element systematics rule out significant accumulation of $\mathrm{Mg}$-rich phases such as clinopyroxene or olivine in these samples. For this reason, the high $\mathrm{Mg} \#$ is compatible with the LPA basaltic andesites being primitive melts despite $\mathrm{SiO}_{2}$ contents of 53.5-57.5 wt $\%$, 

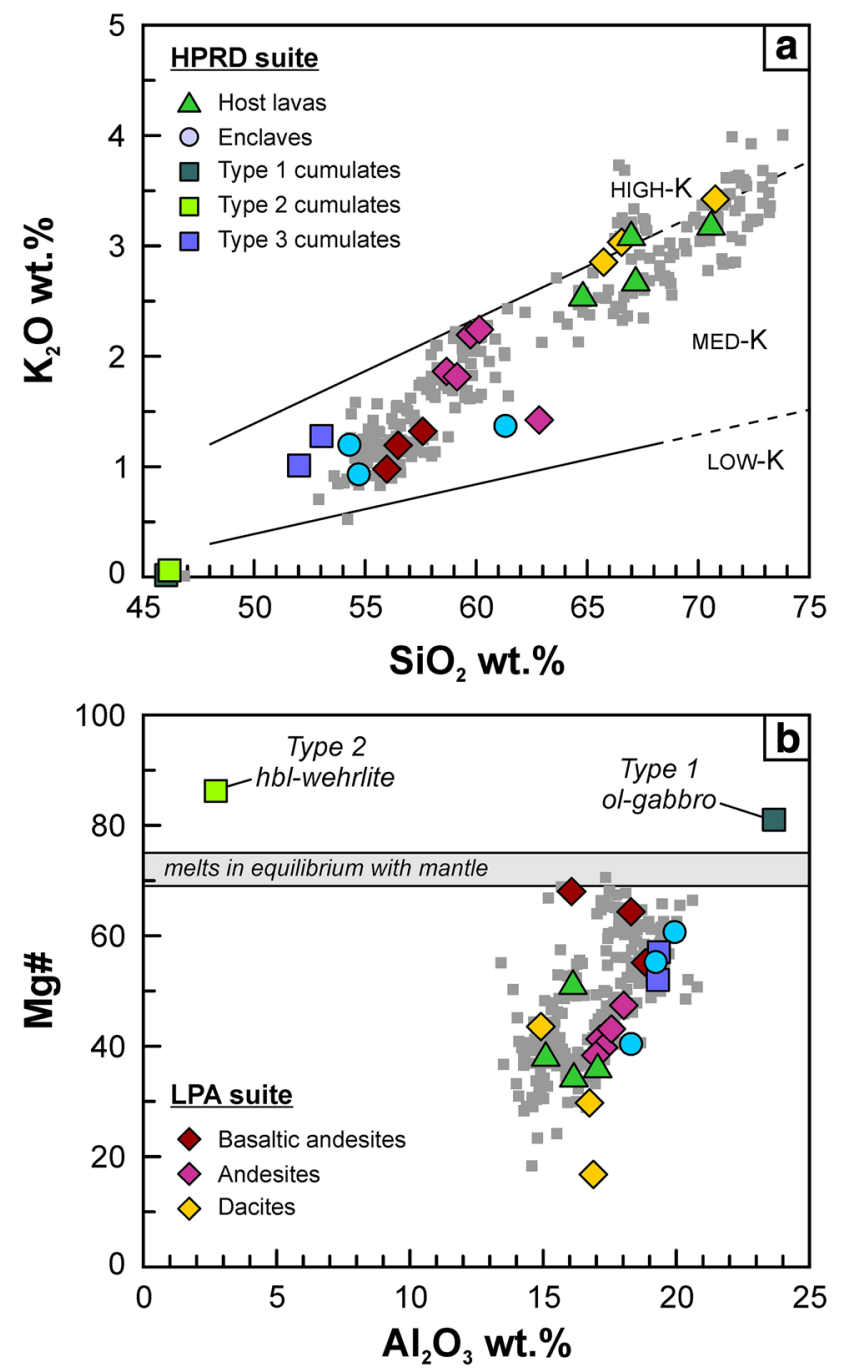

Fig. 4 Major element variation of Nisyros eruptive products. Cumulates for which whole rock data are available, either by direct bulk analysis or by point counting in the case of homogeneous, unzoned cumulate phases, are included. The Nikia flow (NLF) Type 3 cumulates represent bulk analyses that are affected by the infiltration of rhyolitic melt and do, therefore, not reflect the true bulk composition of the subtractive mineral assemblage. Grey squares are literature data, see text for references. Data are reported on a volatile-free basis with all $\mathrm{Fe}$ as $\mathrm{FeO}^{*}$. In a, the low- $\mathrm{K}$ to high-K classification is after Le Maitre et al. (1989). In b, the grey bar represents the range of primary melts in equilibrium with mantle olivine $\left(\mathrm{Fo}_{90}\right.$; Roeder and Emslie 1970)

and hence they can be classified as primitive andesites (following the definition of Kelemen et al. 2003). Mafic enclaves hosted in the HPRD suite largely overlap in composition with LPA basaltic andesites, although the former generally have lower $\mathrm{Mg \#} \mathrm{(50-60)} \mathrm{and} \mathrm{SiO}_{2}$ contents, and $\mathrm{Al}_{2} \mathrm{O}_{3}$ contents up to $20.5 \mathrm{wt} \%$ are found in enclaves in the Profitis Ilias domes (PFI; Braschi et al. 2012). The lack of significant trace element and isotopic variations between the most primitive LPA and HPRD samples suggests that there is no pronounced difference in primary melts feeding the two suites (Klaver et al. 2016).

Cumulates in the HPRD suite have lower $\mathrm{SiO}_{2}$ content than any of the extrusive products. The bulk composition of the plagioclase-amphibolite heteradcumulates in the Nikia flow is relatively similar to HPRD enclaves due to the presence of intercumulus rhyolitic melt but is nevertheless distinct in, for instance, higher $\mathrm{TiO}_{2}$ contents. A plagioclase-clinopyroxene-olivine and an amphibole-wehrlite orthocumulate are characterised by higher $\mathrm{Mg \#}$ and lower $\mathrm{SiO}_{2}$ contents than the extrusive products, but have highly variable $\mathrm{Al}_{2} \mathrm{O}_{3}$ contents depending on the presence of plagioclase.

\section{Mineral compositions}

An overview of the variation in plagioclase, pyroxene and olivine compositions in the Nisyros volcanic rocks and cumulates is shown in Fig. 5 and amphibole major element variations are presented in Fig. 6. The samples have been grouped according to their petrographic features in a lowporphyricity andesite (LPA) and high-porphyricity rhyodacites (HPRD) suite and further subdivided on the basis of bulk rock composition. Detailed major element variation diagrams for all minerals are provided in the online supplementary material.

\section{Clinopyroxene}

Nisyros clinopyroxenes are diopsides to augites that range in composition from $\mathrm{Mg \#} \mathrm{91-65} \mathrm{and} \mathrm{are} \mathrm{characterised} \mathrm{by}$ a large variation in $\mathrm{Al}_{2} \mathrm{O}_{3}, \mathrm{TiO}_{2}, \mathrm{CaO}$ and $\mathrm{Cr}$ contents. In general, clinopyroxene with the highest $\mathrm{Mg \#}$ and up to $6000 \mathrm{ppm} \mathrm{Cr}$ is restricted to the LPA basaltic andesites; clinopyroxene in HPRD suite cumulates has lower Mg\# (89-75) and $\mathrm{Cr}$ contents $(<3000 \mathrm{ppm})$. The LPA andesites and HPRD (rhyo)dacites host clinopyroxene with Mg\# generally $<80$ and $\mathrm{Cr}$ contents below detection limit. Clinopyroxene $\mathrm{TiO}_{2}$ contents vary between the two suites: LPA andesite clinopyroxene contains $0.5-1.5 \mathrm{wt} \% \mathrm{TiO}_{2}$ while the $\mathrm{TiO}_{2}$ content is $<0.5 \mathrm{wt} \%$ in the HPRD suite. Aluminium concentrations are variable: mostly $<3.5 \mathrm{wt} \% \mathrm{Al}_{2} \mathrm{O}_{3}$ in the LPA suite, but up to $9 \mathrm{wt} \%$ in cumulate crystals.

\section{Amphibole}

Amphibole displays a limited variation in $\mathrm{SiO}_{2}$ (40-45 wt\%) and $\mathrm{Al}_{2} \mathrm{O}_{3}(8-15 \mathrm{wt} \%)$ concentrations, predominantly at the low- $\mathrm{SiO}_{2} /$ high- $\mathrm{Al}_{2} \mathrm{O}_{3}$ end of the range displayed by amphibole in arc volcanoes (e.g., Ridolfi et al. 2010). A bimodal amphibole population with low-temperature magnesio-hornblende and high-temperature tschermakitic pargasite, which 
Fig. 5 Overview of the composition (An\% for plagioclase, $\mathrm{Mg \#}$ for olivine, amphibole, clino- and orthopyroxene) of major phases in the magmatic products of Nisyros. The samples have been grouped based on petrography and field occurrence in a lowporphyricity andesite (LPA) and high-porphyricity (rhyo)dacite (HPRD) suite and are sorted by increasing $\mathrm{SiO}_{2}$ content downward for the LPA and HPRD suite lavas and enclaves, and median clinopyroxene $\mathrm{Mg \#}$ for the cumulates. Abbreviations for the volcanic units after Volentik et al. (2005b)

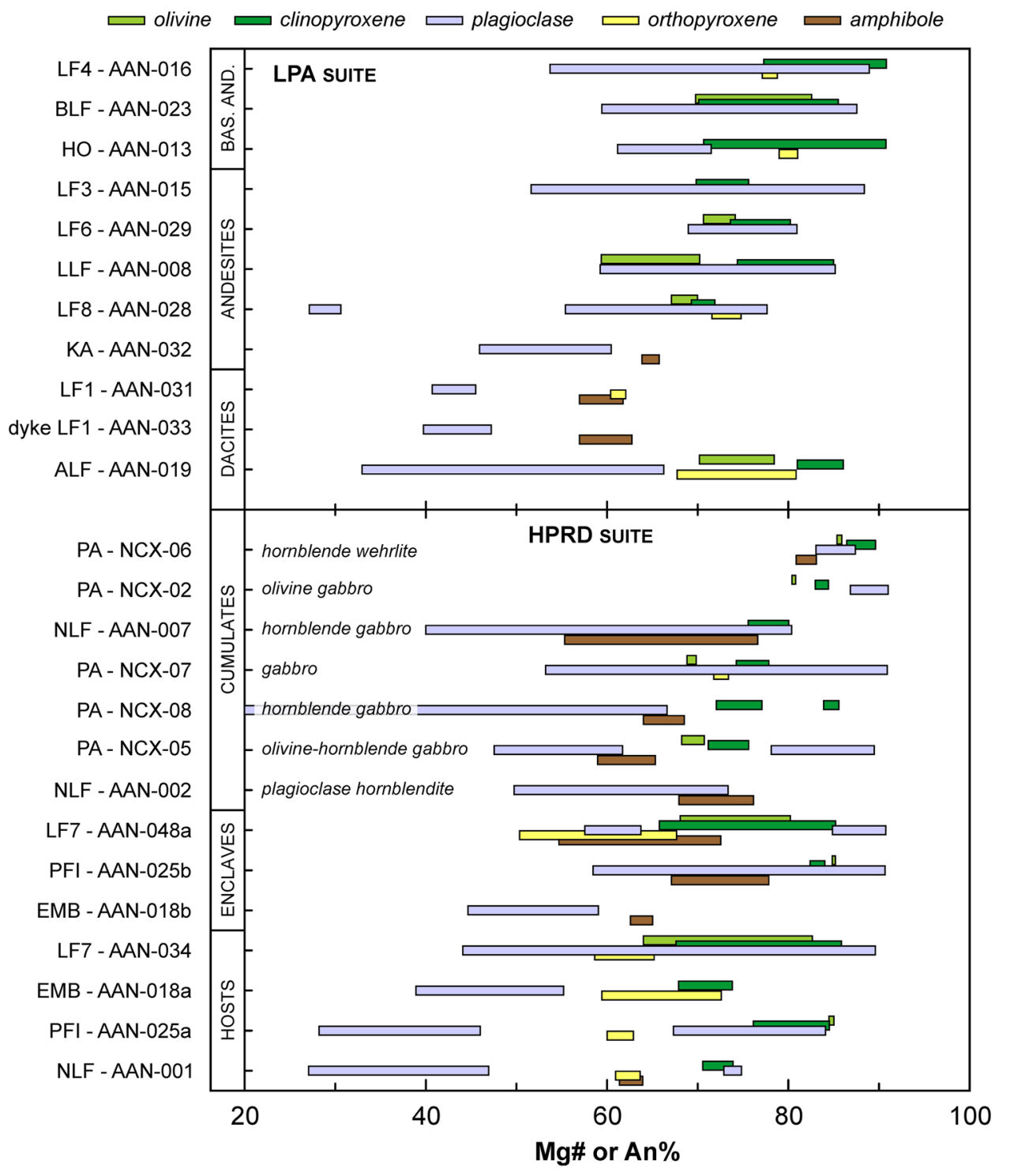

is characteristic for many intermediate arc lavas (e.g., Mt. Hood, Unzen, Soufrière Hills; see Kent 2014 for a compilation), has not been observed (Fig. 6). Instead, amphibole compositions are restricted to high $\mathrm{Al} / \mathrm{Si}$ magnesio-hastingsites and tschermakitic pargasites. Amphibole in the HPRD suite enclaves overlaps with the high-temperature population commonly found in arcs, while $\mathrm{Al}_{2} \mathrm{O}_{3}$ is lower and $\mathrm{TiO}_{2}$ and $\mathrm{Na}_{2} \mathrm{O}$ contents are higher in LPA dacite amphibole (Fig. 6). In addition, acicular amphibole in the Emborio dome enclave is compositionally similar to the coarse amphibole in the LPA dacites, indicating that the chemical composition of the amphiboles does not correlate with their morphology.

\section{Plagioclase}

Plagioclase varies from $\mathrm{An}_{24}$ to $\mathrm{An}_{91}$ in the Nisyros sample suite. Orthoclase contents $\left(\mathrm{Or}_{0.1-5}\right)$ are higher in LPA suite (basaltic) andesites than in HPRD enclaves and host lavas in the range $\mathrm{An}_{50-80}$ but overlap at $\mathrm{An}_{>80}$. The highest $\mathrm{An} \%$ is found in cumulates hosted in the HPRD suite and in LPA basaltic andesite phenocrysts. In the cumulates, plagioclase can display zoning and resorption from calcic $\left(\mathrm{An}_{>80}\right)$ cores to more sodic rims. Reverse zoning is rare, in contrast to plagioclase phenocrysts in the LPA suite that often preserve complex and oscillatory zoning patterns (Fig. 2d). In the LPA suite, crystals with normal and reverse zoning to a common rim composition frequently occur within the same thin section. HPRD suite host lavas and enclaves often contain similar, often bimodal plagioclase populations.

\section{Olivine and orthopyroxene}

Olivine in the Nisyros sample suite ranges from $\mathrm{Fo}_{86}$ to $\mathrm{Fo}_{60}$. The most forsteritic olivine $\left(\mathrm{Fo}_{86}\right)$ is found in a 

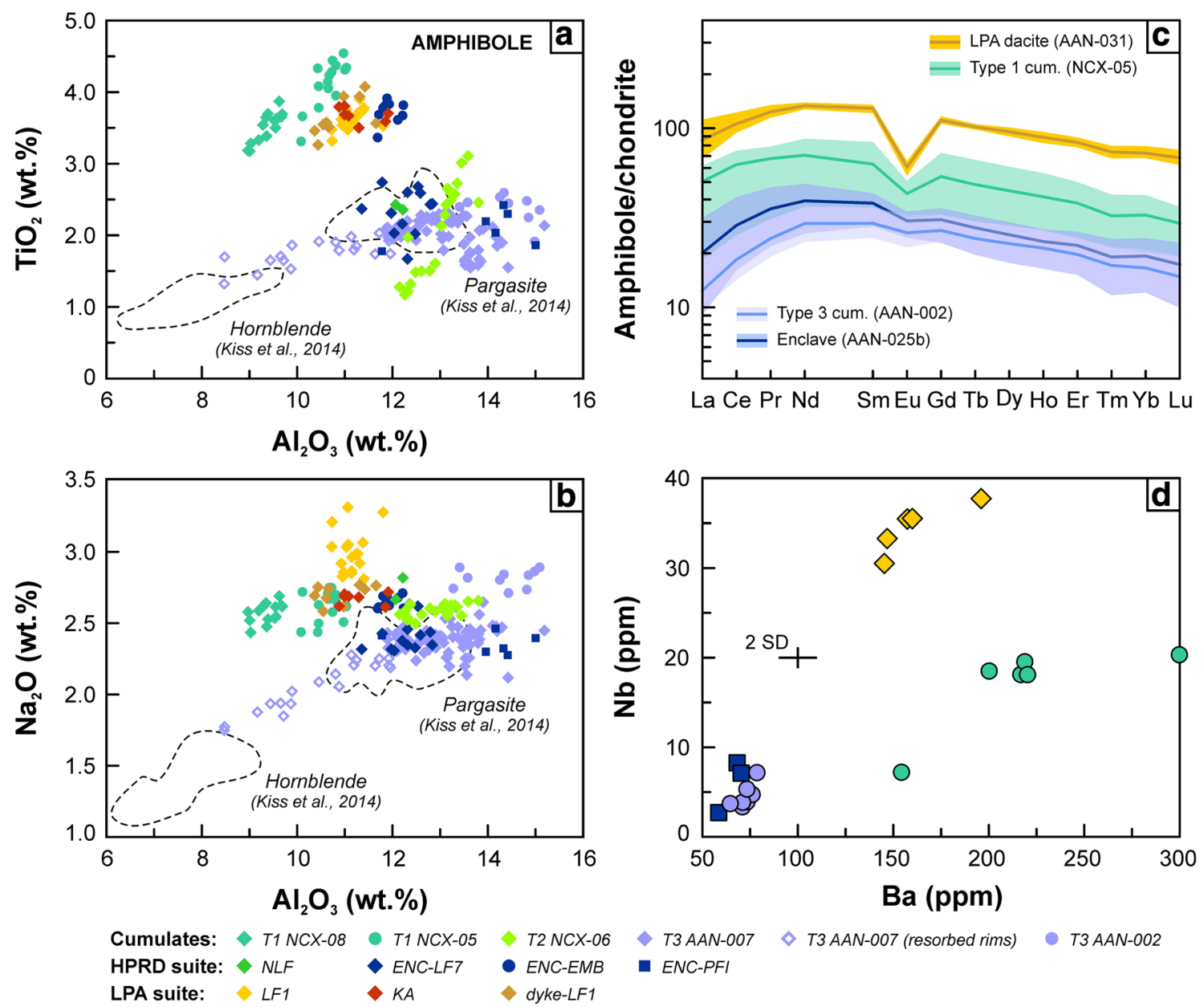

Fig. 6 Amphibole major and trace element composition. The samples have been grouped based on petrography and field occurrence in a low-porphyricity andesite (LPA) and high-porphyricity (rhyo)dacite (HPRD) suite. A typical example of a bimodal amphibole population in intermediate arc rocks (Kiss et al. 2014) is shown for comparison in $\mathbf{a}$ and $\mathbf{b}$. Nisyros amphibole lacks such a bimodal distribution

hornblende-wehrlite cumulate and in enclaves and host lavas of the PFI domes. Forsterite content is lower in the other HPRD cumulates and LPA andesites. Nickel contents are variable and show a broadly positive correlation with Fo content (see supplementary material). At $\mathrm{Fo}_{72}-\mathrm{Fo}_{82}$, olivine in the HPRD lavas, enclaves and cumulates generally has lower Ni contents compared to olivine in the LPA basaltic andesites. The latter is also characterised by lower $\mathrm{CaO}$ contents (ca. $0.10 \mathrm{wt} \%$ ) compared to the majority of Nisyros olivine $(0.1-0.2 \mathrm{wt} \% \mathrm{CaO})$.

Two separate groups of orthopyroxene compositions can be distinguished that constitute a bimodal distribution in Mg\#. Orthopyroxene is most abundant in the HPRD hosts and LPA dacites where it displays a narrow range in Mg\# from 60 to 65. Although orthopyroxene Mg\# in the HPRD and LPA dacites overlaps, the two groups are separated by higher $\mathrm{Al}_{2} \mathrm{O}_{3}$ and as hornblende in equilibrium with a felsic melt is not present; only resorbed rims in AAN-007 trend towards the low-temperature amphibole population. In $\mathbf{c}$, the range and mean rare-earth element compositions are shown; chondrite values are from McDonough and Sun (1995). Cumulates are grouped in Types 1-3 (T1-3), as discussed in the text

$\mathrm{TiO}_{2}$ in the LPA dacite orthopyroxenes, which is similar to the clinopyroxene systematics. Orthopyroxene ranges from $\mathrm{Mg} \# 78$ to 83 in the LPA basaltic andesites; orthopyroxene in ALF and cumulate fragments has Mg\# intermediate between the two groups. The $\mathrm{Al}_{2} \mathrm{O}_{3}$ content of Nisyros orthopyroxene ranges from 1.0 to $1.5 \mathrm{wt} \%$ in the LPA basaltic andesites to $0.3-1.0 \mathrm{wt} \%$ in the HPRD suite and LPA dacites; $\mathrm{TiO}_{2}$ contents are generally lower than $0.4 \mathrm{wt} \%$.

\section{Discussion}

\section{Distinction between the LPA and HPRD suites}

We propose a new division of the Nisyros volcanic deposits based on field relationships and petrographic features. The 
main distinction between the two suites is the pronounced macro- and microscopic evidence for disequilibrium and magma mixing and mingling in the HPRD suite, and lack thereof in the LPA suite. For example, both suites include dacites, but the rare LPA dacites contain $<15$ vol\% phenocrysts set in a glassy groundmass while HPRD dacites have a porphyritic texture with $20-40$ vol\% crystals up to $1 \mathrm{~cm}$ in size and a coarse microlite matrix. Phenocryst phases also differ between the two as illustrated by the lack of primary amphibole and presence of clinopyroxene in the HPRD dacites. Moreover, the HPRD dacites contain mafic enclaves and a wide variety of microcumulates and xenocrysts. Distinguishing the two suites is thus straightforward in the field and on the hand specimen to thin section scale.

Porphyritic andesites and dacites are common eruptive products of arc volcanoes and often show textural and geochemical evidence for (extensive) hybridisation (e.g., Humphreys et al. 2009; Reubi and Blundy 2009; Cooper and Kent 2014; Kent 2014; Blum-Oeste and Wörner 2016). Such hybrid andesites are believed to tap shallow, crystalrich mush systems that have stalled in the upper crust due to decompression-induced degassing and rapid crystallisation (e.g., Blundy and Cashman 2005; Annen et al. 2006; Bachmann and Huber 2016). Due to their high viscosity, these mush systems spend the majority of the time close to the solidus in an uneruptible state, but can be rapidly remobilised and erupted in response to recharge by a volatilerich mafic magma (e.g., Cooper and Kent 2014; Parmigiani et al. 2014; Bergantz et al. 2015). Field relationships and textures of the HPRD (rhyo)dacites are very similar to these hybrid, reactivated mushes. High crystal contents, a coarse microlite groundmass and plagioclase-dominated mineralogy are diagnostic features. Moreover, the HPRD lavas include abundant mafic enclaves with a texture of acicular amphibole and plagioclase that attests to quench crystallisation upon injection in the cooler (rhyo)dacitic host (Bacon 1986; Vanderkluysen et al. 2005a; Braschi et al. 2014) and hence supports mafic recharge as a likely eruption trigger (Bachmann et al. 2012; Braschi et al. 2012, 2014). Magma mingling and disaggregation of the enclaves leads to crystal transfer from the enclaves to the (rhyo)dacitic host and vice versa and can thus account for the complex zoning patterns recorded by HPRD crystals as well as similar, often bimodal plagioclase distributions in the enclaves and hosts (Humphreys et al. 2009; Braschi et al. 2014; Bergantz et al. 2015). Given their textural and compositional similarity, it is likely that all HPRD units originated from a shallow crystal-rich mush system that was reactivated by mafic recharge and that this process was not restricted solely to the youngest PFI domes on Nisyros.

The crystal-poor, enclave-free LPA andesites and dacites form a striking contrast with the HPRD suite.
Andesites can be generated through extensive hybridisation of felsic and mafic melts in evolved mush systems (e.g., Reubi and Blundy 2009; Kent 2014) but this process is not tenable for the LPA andesites. The main argument against a hybrid origin for the LPA andesites and dacites is the lack of geochemical evidence for mixing (e.g., Wyers and Barton 1989; Vanderkluysen et al. 2005a). The LPA andesites and dacites do not fall on mixing lines between HPRD rhyodacites and primitive samples as, for instance, in a $\mathrm{K}_{2} \mathrm{O}$ versus $\mathrm{SiO}_{2}$ diagram (Fig. 4). In addition, a hybrid origin is excluded by the low crystal content and lack of macro- and microscopic evidence for magma mixing between the required mafic and felsic components. Disequilibrium textures related to mixing between primitive and evolved melts, such as seen in the HPRD suite, are not present in the LPA andesites and dacites. There is no evidence for a felsic mixing component as no crystals with a HPRD (rhyo)dacite signature are found in the LPA crystal record. Plagioclase and clinopyroxene in the LPA andesites have $\mathrm{An} \%$ and $\mathrm{Mg \#}$ intermediate between the LPA basaltic andesites and HPRD rhyodacites, but minor and trace element contents in these phases are distinct. This is best illustrated by the $\mathrm{TiO}_{2}$ content of clinopyroxene, which is higher in LPA andesites than in both the LPA basaltic andesites and HPRD suite and thus inconsistent with crystallisation from a hybrid andesitic melt (Fig. 7). In addition, clinopyroxene in LPA andesites has higher $\mathrm{Al}_{2} \mathrm{O}_{3}$ and lower La/Sm (see supplementary material) compared to the HPRD suite.

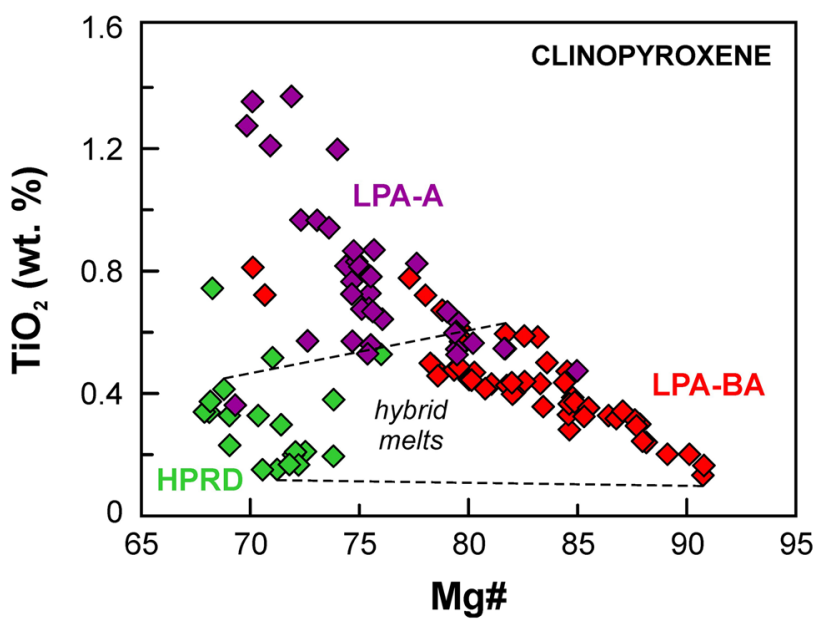

Fig. 7 Clinopyroxene $\mathrm{TiO}_{2}$ content versus $\mathrm{Mg} \#$ showing the difference between the LPA basaltic andesites (LPA-BA) and andesites (LPA-A) and the HPRD suite. Andesites in the LPA suite have higher $\mathrm{TiO}_{2}$ contents than the other groups and are not consistent with crystallisation from a hybrid melt. See supplementary material for an extended diagram showing individual samples 


\section{Equilibrium mineral assemblages in the HPRD suite}

The HPRD suite displays a wide variation in crystal components that range from phenocrysts that are in apparent equilibrium with the melt to antecrysts, xenocrysts, microcumulates and crystals derived from disaggregated enclaves, which are in textural and compositional disequilibrium. As these disequilibrium assemblages carry important information on the structure of Nisyros' plumbing system, we endeavour to identify mineral assemblages that appear to be in inter-mineral equilibrium, even though these might not be in equilibrium with the melt in which they are hosted. Cumulate fragments and microcumulates in the HPRD suite can be divided into three groups that are present in varying abundance, which are discussed below. An overview of these mineral assemblages is given in Table 1.

\section{HPRD phenocryst assemblage}

The HPRD (rhyo)dacites have a common equilibrium phenocryst assemblage of plagioclase $\left(\mathrm{An}_{20-60}\right)$, orthopyroxene (Mg\# 60-64), ilmenite and clinopyroxene that often occur in clusters (Fig. 2). In contrast, amphibole phenocrysts are conspicuously absent despite being a common phase in similar (rhyo)dacitic arc magmas worldwide. Such magmas often display a bimodal distribution of amphibole compositions with a low-temperature population in equilibrium with the felsic host and a high-temperature population derived from the mafic recharge magma (Fig. 6; e.g., Coombs et al. 2013; Kent 2014; Kiss et al. 2014). Rare amphibole crystals in the HPRD (rhyo)dacites are resorbed and compositionally distinct from low- $T$ amphibole but overlap with hightemperature compositions found in the enclaves, and thus appear to be derived from the mafic enclaves (Wyers and Barton 1989). The lack of primary amphibole likely results from a combination of higher magmatic temperatures and lower $\mathrm{H}_{2} \mathrm{O}$ contents compared to other hybrid arc magmas that place the HPRD (rhyo)dacites outside the stability field of amphibole (e.g., Bachmann et al. 2012).

\section{Type 1 cumulates}

The most common Type 1 cumulates invariably contain Anrich plagioclase $\left(\mathrm{An}_{80-90}\right)$ and clinopyroxene (Mg\# 73-86),

Table 1 Overview of equilibrium mineral assemblages that can be recognised in the LPA and HPRD suites

\begin{tabular}{|c|c|c|c|c|c|c|}
\hline & Assemblage & Occurrence & Plagioclase & $\mathrm{Cpx}$ & Olivine & Amphibole \\
\hline \multicolumn{7}{|l|}{ HPRD suite } \\
\hline Host lavas & $\mathrm{Pl}+\mathrm{Opx}+\mathrm{Mt} \pm \mathrm{Cpx}$ & Phenocrysts & An $20-50$ & $\begin{array}{l}\mathrm{Mg} \# 65-75 \\
<2 \mathrm{wt} \% \mathrm{Al}_{2} \mathrm{O}_{3} \\
<0.5 \mathrm{wt} \% \mathrm{TiO}_{2}\end{array}$ & $\mathrm{n} / \mathrm{p}$ & $\mathrm{n} / \mathrm{p}$ \\
\hline Enclaves & $\mathrm{Pl}+\mathrm{Hbl}$ & $\begin{array}{l}\text { Quench assem- } \\
\text { blage, acicular } \\
\text { crystals }\end{array}$ & An $50-65$ & $\mathrm{n} / \mathrm{p}$ & $\mathrm{n} / \mathrm{p}$ & $\begin{array}{l}\mathrm{Mg} \# 60-65 \\
<13 \mathrm{wt} \% \mathrm{Al}_{2} \mathrm{O}_{3}\end{array}$ \\
\hline $\begin{array}{l}\text { Type } 1 \text { cumu- } \\
\text { lates }\end{array}$ & $\mathrm{Pl}+\mathrm{Cpx} \pm \mathrm{Ol} \pm \mathrm{Hbl} \pm \mathrm{Ox}$ & $\begin{array}{l}\text { Microcumulates } \\
\text { in host lavas } \\
\text { and enclaves; } \\
\text { discrete frag- } \\
\text { ments }\end{array}$ & $\begin{array}{l}\text { An } 85-90 \text { cores } \\
\text { An } 60 \text { rims }\end{array}$ & $\begin{array}{l}\mathrm{Mg} \# 75-85 \\
<4 \mathrm{wt} \% \mathrm{Al}_{2} \mathrm{O}_{3} \\
<0.7 \mathrm{wt} \% \mathrm{TiO}_{2}\end{array}$ & $\begin{array}{l}\text { Fo } 70-82 \\
<800 \mathrm{ppm} \mathrm{Ni}\end{array}$ & $\begin{array}{l}\mathrm{Mg \#} \sim 65 \\
<11 \mathrm{wt} \% \mathrm{Al}_{2} \mathrm{O}_{3}\end{array}$ \\
\hline $\begin{array}{l}\text { Type } 2 \text { cumu- } \\
\text { lates }\end{array}$ & $\mathrm{Cpx}+\mathrm{Ol} \pm \mathrm{Hbl} \pm \mathrm{Pl}$ & $\begin{array}{l}\text { Rare microcu- } \\
\text { mulates; single } \\
\text { large fragment }\end{array}$ & An $>90$ & $\begin{array}{l}\mathrm{Mg} \# 80-89 \\
2-6 \mathrm{wt} \% \mathrm{Al}_{2} \mathrm{O}_{3} \\
0.5-1 \mathrm{wt} \% \mathrm{TiO}_{2}\end{array}$ & $\begin{array}{l}\text { Fo }>80 \\
700-1400 \mathrm{ppm} \\
\mathrm{Ni}\end{array}$ & $\begin{array}{l}\mathrm{Mg} \# \sim 81 \\
13-14 \mathrm{wt} \% \mathrm{Al}_{2} \mathrm{O}_{3}\end{array}$ \\
\hline $\begin{array}{l}\text { Type } 3 \text { cumu- } \\
\text { lates }\end{array}$ & $\mathrm{Hbl}+\mathrm{Pl}+\mathrm{Ox} \pm \mathrm{Cpx}$ & $\begin{array}{l}\text { Cumulate frag- } \\
\text { ments; Hbl } \\
\text { replaces Cpx }\end{array}$ & An $70-80$ & $\begin{array}{l}\mathrm{Mg} \# 75-80 \\
7-9 \mathrm{wt} \% \mathrm{Al}_{2} \mathrm{O}_{3} \\
0.8-1.8 \mathrm{wt} \% \\
\mathrm{TiO}_{2}\end{array}$ & $\mathrm{n} / \mathrm{p}$ & $\begin{array}{l}\mathrm{Mg} \# 70-80 \\
12-15 \mathrm{wt} \% \mathrm{Al}_{2} \mathrm{O}_{3}\end{array}$ \\
\hline \multicolumn{7}{|l|}{ LPA suite } \\
\hline $\begin{array}{l}\text { Basaltic } \\
\text { andesites }\end{array}$ & $\mathrm{Pl}+\mathrm{Cpx} \pm \mathrm{Opx} \pm \mathrm{Ol}$ & $\begin{array}{l}\text { Phenocrysts and } \\
\text { antecrysts }\end{array}$ & An $60-90$ & $\begin{array}{l}\mathrm{Mg} \# 77-91 \\
<3 \mathrm{wt} \% \mathrm{Al}_{2} \mathrm{O}_{3} \\
<0.8 \mathrm{wt} \% \mathrm{TiO}_{2}\end{array}$ & $\begin{array}{l}\text { Fo } 70-83 \\
600-1600 \mathrm{ppm} \\
\mathrm{Ni}\end{array}$ & $\mathrm{n} / \mathrm{p}$ \\
\hline Andesites & $\mathrm{Pl}+\mathrm{Cpx} \pm \mathrm{Ox} \pm \mathrm{Ol}$ & $\begin{array}{l}\text { Phenocrysts and } \\
\text { antecrysts }\end{array}$ & An $50-90$ & $\begin{array}{l}\mathrm{Mg} \# 68-85 \\
<4 \mathrm{wt} \% \mathrm{Al}_{2} \mathrm{O}_{3} \\
0.5-1.5 \mathrm{wt} \% \\
\mathrm{TiO}_{2}\end{array}$ & $\begin{array}{l}\text { Fo } 60-72 \\
600-1600 \mathrm{ppm} \\
\text { Ni }\end{array}$ & $\mathrm{n} / \mathrm{p}$ \\
\hline Dacites & $\mathrm{Pl}+\mathrm{Opx}+\mathrm{Hbl}+\mathrm{Ox}$ & Phenocrysts & An $40-50$ & $\mathrm{n} / \mathrm{p}$ & $\mathrm{n} / \mathrm{p}$ & $\begin{array}{l}\mathrm{Mg} \# 57-67 \\
10-12 \mathrm{wt} \% \mathrm{Al}_{2} \mathrm{O}_{3}\end{array}$ \\
\hline
\end{tabular}

Mineral abbreviations: $P l$ plagioclase, $O p x$ orthopyroxene, $C p x$ clinopyroxene, $O x \mathrm{Fe}$-Ti-oxides, $H b l$ hornblende, $O l$ olivine, $n / p$ not present 
with or without olivine, amphibole and $\mathrm{Fe}$-Ti-oxides. Their main distinguishing feature is the co-occurrence of calcic plagioclase $\left(\sim \mathrm{An}_{90}\right)$ and relatively evolved $(\mathrm{Mg \#} \leq 85)$ clinopyroxene and olivine. The presence of interstitial amphibole and bimodal plagioclase compositions suggest that several of the Type 1 cumulates have reacted with percolating melts. Olivine and clinopyroxene $\mathrm{Mg \#}$ are generally lower in the cumulates with interstitial amphibole. Type 1 cumulates occur as microcumulates in the HPRD enclaves and lavas and as fragments in pyroclastic deposits of the Lies tuff cone (Fig. 3). When entrained in a (rhyo)dacitic melt, the microcumulates are in disequilibrium as indicated by pronounced normal zoning of olivine, clinopyroxene and plagioclase and the presence of orthopyroxene mantles around olivine towards contacts with the host melt (Fig. 3d). The preservation of $\mathrm{Fe}-\mathrm{Mg}$ zoning profiles in olivine indicates that cooling was sufficiently rapid to inhibit complete re-equilibration. Diffusion modelling of $\mathrm{Mg}-\mathrm{Fe}$ zoning in olivine can be used to constrain timescales of magma mixing (e.g., Costa and Dungan 2005; Turner and Costa 2007), but this was not undertaken due the scarcity of suitable olivine grains. Nevertheless, a timescale of $\ll 1 \mathrm{kyr}$ between mixing and eruption can safely be assumed based on the pronounced zoning in olivine in these micro-enclaves. Similar zoned olivines from the Nea Kameni dacites, Santorini, suggest that less than 1 year has elapsed between mingling of the olivine crystals into the (rhyo)dacitic host and eruption (Martin et al. 2008).

\section{Type 2 cumulates}

Rare Type 2 cumulates comprise plagioclase-free or -poor assemblages that contain more primitive (higher $\mathrm{Mg \# )}$ olivine than Type 1 cumulates. Type 2 microcumulates typically occur as clusters of anhedral crystals ( $<10$ grains) and are predominantly found in the PFI domes and enclaves. The exception is a larger hornblende-wehrlite cumulate fragment (NCX-06; Fig. 3e). This fragment consists of roughly equal proportions of olivine and clinopyroxene and $\sim 10 \mathrm{vol} \%$ amphibole. It has a non-equilibrated texture characterised by euhedral olivine and poikilitic clinopyroxene. Amphibole typically fills the intercumulus space and the cusps between adjacent grains, but does not appear to be forming at the expense of clinopyroxene. No replacement of clinopyroxene with amphibole along cracks or cleavage planes is observed, in contrast to the Type 3 cumulates described below. A single isolated plagioclase crystal $\left(\mathrm{An}_{86}\right)$ is present, as are rare plagioclase inclusions in amphibole, but the sample is essentially plagioclase-free $(<0.5 \mathrm{vol} \%)$. Apart from the general scarcity of plagioclase, Type 2 cumulates are distinguished by high $\mathrm{Al}_{2} \mathrm{O}_{3}$ contents in clinopyroxene (up to $7 \mathrm{wt} \%$ in individual crystals; Fig. 8). Type 1 and 2 cumulates are clearly distinct, but their occurrence is not mutually exclusive and they can occur in the same unit (e.g., in PFI and LF7).

\section{Type 3 cumulates}

The Type 2 cumulates transition into Type 3 plagioclase + amphibole \pm clinopyroxene cumulates that have been found exclusively in the Nikia flow (NLF). Amphibole in these cumulates occurs in various forms. It replaces clinopyroxene along cracks and cleavage planes but also mantles clinopyroxene with less clear textural evidence for reaction-replacement (Fig. 9). Amphibole, clinopyroxene, magnetite and plagioclase cores are in apparent equilibrium with each other in the centre of crystal clusters. Euhedral plagioclase and amphibole crystals extend outwards and are in disequilibrium with the rhyolitic host melt, as indicated by resorption of amphibole and strong zoning of plagioclase from $\mathrm{An}_{80}$ cores to $\mathrm{An}_{<55}$ rims (Fig. 9). The preservation of zoning profiles indicates that infiltration of the rhyolitic melt occurred shortly before eruption. Similar clinopyroxene-amphibole replacement textures have been observed in arc root complexes (e.g., Dessimoz et al. 2012; Bouilhol et al. 2015) and cumulate nodules in arc lavas (Smith 2014; Cooper et al. 2016). High Mg\# (67-76; with all $\mathrm{Fe}$ as $\mathrm{Fe}^{2+}$ ), low trace element contents and $\mathrm{Eu} / \mathrm{Eu}^{*}>0.9$ (Fig. 6) suggest that hornblende in the Type 3 cumulates crystallised from relatively primitive melts, in contrast to interstitial amphibole in the Type 1 cumulates. Clinopyroxene in the Type 3 cumulates has the highest $\mathrm{Al}_{2} \mathrm{O}_{3}$ content found on Nisyros (up to 9 wt $\%$ ).

\section{Constraining the origin of the Nisyros cumulates}

Phenocrysts in the LPA and HPRD suites broadly overlap with cumulate crystals in terms of An\% (plagioclase), Fo\% (olivine) and $\mathrm{Mg \#} \mathrm{(pyroxenes} \mathrm{and} \mathrm{amphibole;} \mathrm{Fig.} \mathrm{5).} \mathrm{When}$ considered in more detail, however, there are striking differences between phenocryst and cumulate assemblages in terms of paragenesis and mineral compositions (Fig. 8), as is often found in arc suites (e.g., Arculus and Wills 1980; Stamper et al. 2014). Key characteristics of the cumulate suite include the co-occurrence of high-An plagioclase with low-Fo olivine in Type 1 cumulates, the pronounced increase in clinopyroxene $\mathrm{Al}_{2} \mathrm{O}_{3}$ content with decreasing $\mathrm{Mg \#}$ in Type 2 and 3 cumulates, and overall higher clinopyroxene $\mathrm{CaO}$ contents compared to phenocrysts in the LPA suite. These differences likely reflect variations in depth, temperature, water content and oxygen fugacity at which magmas were stored and differentiated in the crust. Constraining these parameters is crucial to understand the magmatic plumbing system of Nisyros. Although the identification of equilibrium mineral assemblages is an important first step, determining the intensive parameters and in particular 

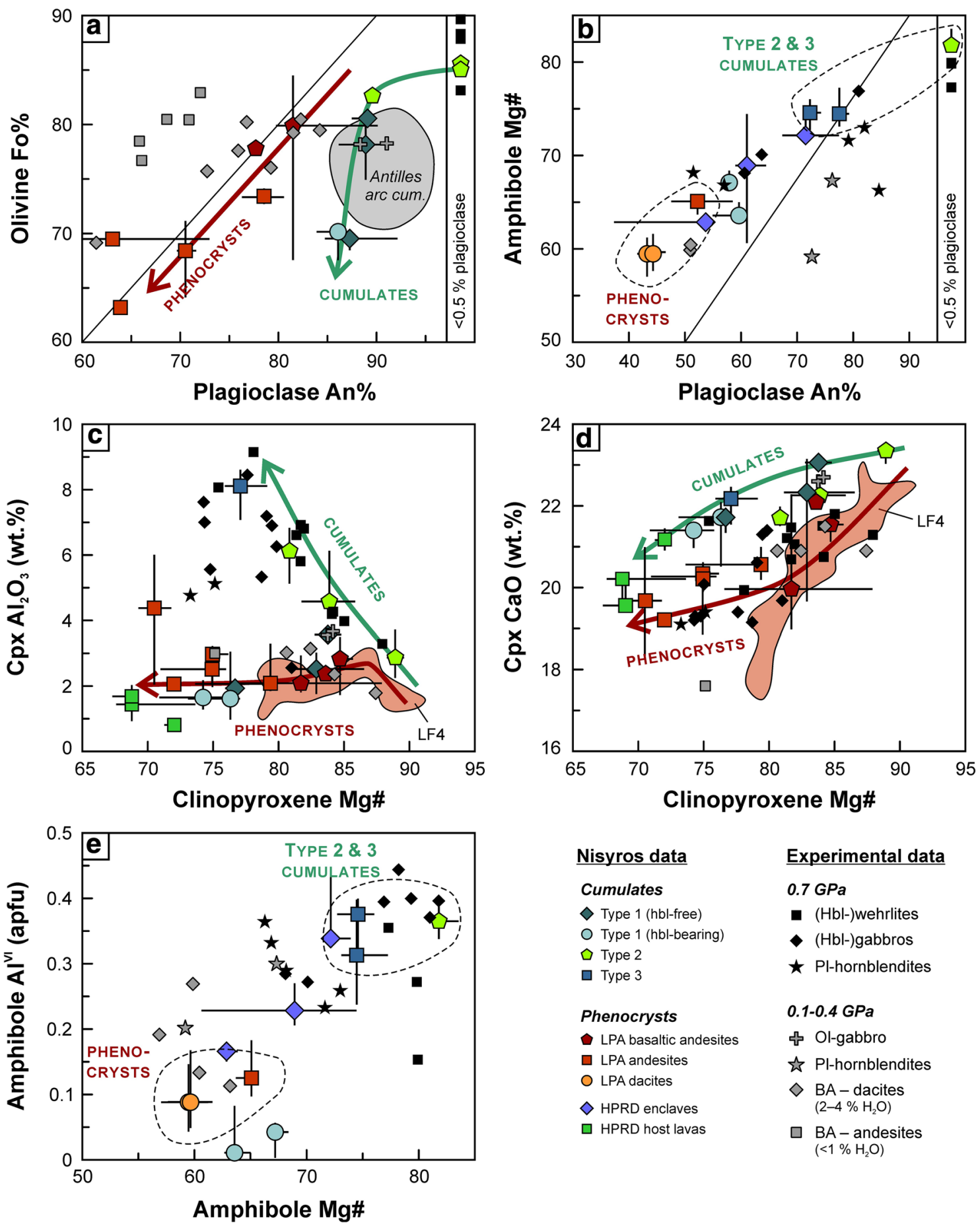

\begin{tabular}{|c|c|}
\hline Nisyros data & Experimental data \\
\hline $\begin{array}{l}\text { Cumulates } \\
\diamond \text { Type } 1 \text { (hbl-free) } \\
\text { O Type } 1 \text { (hbl-bearing) } \\
\square \text { Type } 2 \\
\square \text { Type } 3\end{array}$ & $\begin{array}{l}0.7 \mathrm{GPa} \\
\text { - }(\mathrm{Hbl} \text {-)wehrlites } \\
\star(\mathrm{Hbl}-\text { )gabbros } \\
\star \text { Pl-hornblendites }\end{array}$ \\
\hline $\begin{array}{l}\text { Phenocrysts } \\
\text { LPA basaltic andesites } \\
\text { L LPA andesites } \\
\text { O LPA dacites }\end{array}$ & $\begin{array}{l}\text { 0.1-0.4 GPa } \\
\text { \& Ol-gabbro } \\
\text { is PI-hornblendites } \\
\diamond \mathrm{BA} \text { - dacites }\end{array}$ \\
\hline $\begin{array}{l}\diamond \text { HPRD enclaves } \\
\square \text { HPRD host lavas }\end{array}$ & $\begin{array}{l}\left(2-4 \% \mathrm{H}_{2} \mathrm{O}\right) \\
\mathrm{BA}-\text { andesites } \\
\left(<1 \% \mathrm{H}_{2} \mathrm{O}\right)\end{array}$ \\
\hline
\end{tabular}

Fig. 8 Composition of Nisyros lava and cumulate mineral assemblages, compared with published results of crystallisation experiments: a olivine Fo\% versus plagioclase $\mathrm{An} \%$; b amphibole $\mathrm{Mg \#}$ versus plagioclase $\mathrm{An} \%$; c clinopyroxene $\mathrm{Al}_{2} \mathrm{O}_{3}$ content versus $\mathrm{Mg \#}$; d clinopyroxene $\mathrm{CaO}$ content versus $\mathrm{Mg \#}$; e amphibole $\mathrm{Al}^{\mathrm{VI}}$ versus

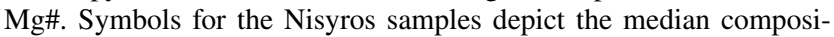
tion; error bars indicate twice the interquartile range. In $\mathbf{a}$ and $\mathbf{b}$, the " $<0.5 \%$ plagioclase" field at the right depicts (near-)plagioclase-free

assemblages. Black and grey symbols represent results of crystallisation experiments at appropriate conditions that are listed in Table 2. Cumulates from the Lesser Antilles arc (Tollan et al. 2012; Stamper et al. 2014; Cooper et al. 2016) are shown for reference. Representative mineral compositions reported by Wyers and Barton (1989) are included. Clinopyroxene in unit LF4 (AAN-016) displays a large variation in $\mathrm{Mg \#}$ and is, therefore, shown as a shaded field rather than a median composition 


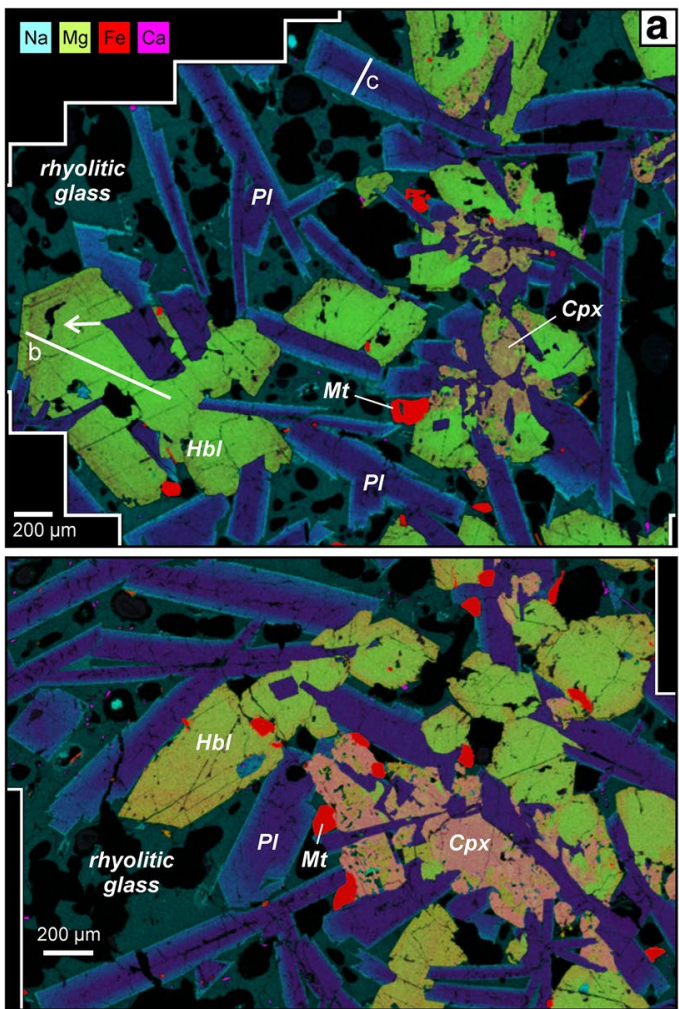

Fig. 9 Type 3 hornblende-gabbro cumulate nodule from the Nikia flow (NLF; AAN-007); a major element maps generated at Cardiff University with a Zeiss Sigma FEG-SEM using dual $150 \mathrm{~mm}^{2}$ energy-dispersive X-ray (EDS) detectors. Amphibole (Hbl, green) and plagioclase $(\mathrm{Pl}$, blue) are zoned towards interstitial rhyolitic glass (teal). Clinopyroxene (Cpx, pinkish-brown) is situated in the centre of crystal clusters and is replaced by amphibole. Despite disequilibrium with the rhyolitic melt, clinopyroxene, amphibole, plagioclase

crystallisation pressures of cumulate suites and arc lavas is notoriously difficult (e.g., Stamper et al. 2014). The singleamphibole thermobarometer of Ridolfi et al. (2010) is appropriate to the Nisyros samples, but we refrain from using this barometer in line with concerns raised by Erdmann et al. (2014) and Putirka (2016). To put constraints on the depth of magma storage and differentiation, we therefore follow the approach of Blundy and Cashman (2008) and Stamper et al. (2014) of correlating observed equilibrium mineral assemblages with those produced in crystallisation experiments. An overview of experimental studies performed on appropriate starting compositions at conditions relevant to subduction zone magmatism is given in Table 2, and Fig. 10 shows a phase diagram for hydrous primary arc magmas compiled from these studies.

\section{Hydrous high-pressure crystallisation}

The Type 2 and 3 cumulates form a textural and compositional continuum from (hornblende-)wehrlites to

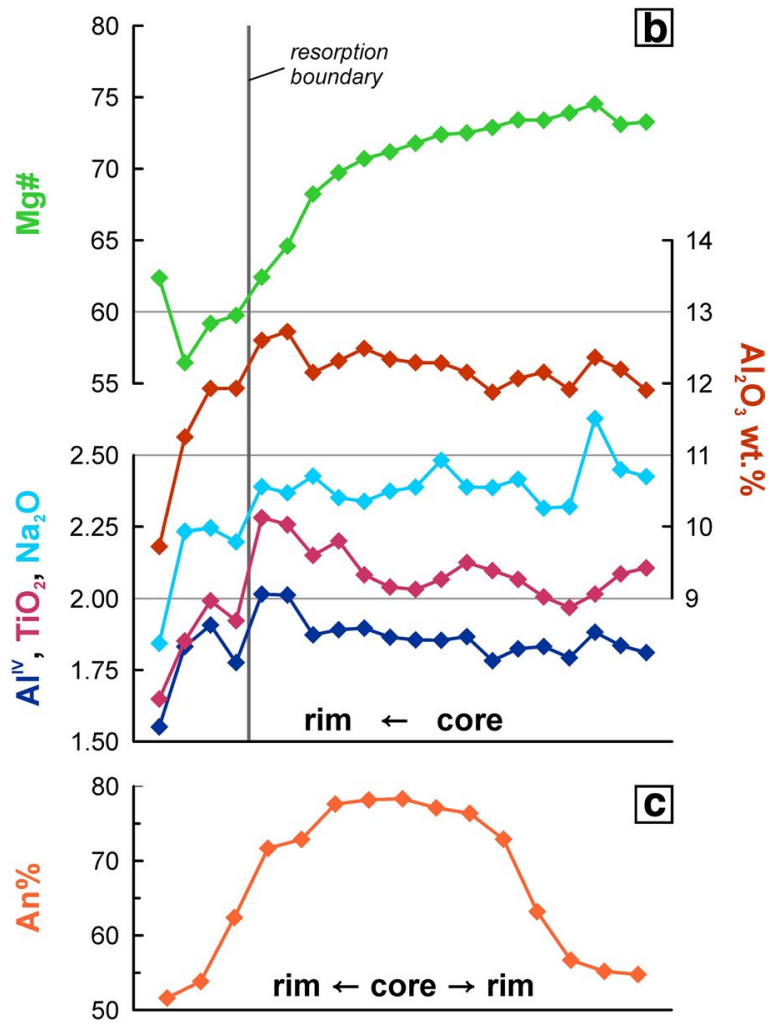

and magnetite (Mt, red) cores are in textural and compositional equilibrium with each other. The white lines in the upper panel show the location of the profiles shown in $\mathbf{b}$ and $\mathbf{c}$; the white arrow indicates the resorption boundary. High-resolution versions of the maps are provided in the supplementary material; $\mathbf{b}$ core-to-rim profile though a zoned, euhedral amphibole crystal shown in a. Length of profile is $\sim 800 \mu \mathrm{m}$; c rim-core-rim An\% profile though a zoned plagioclase crystal shown in a. Length of profile is $\sim 250 \mu \mathrm{m}$

plagioclase-hornblendites that we interpret as the result of progressive fractional crystallisation of a primitive, hydrous melt. Olivine is the first phase to crystallise followed by clinopyroxene, as indicated by the inclusion of euhedral olivine in larger clinopyroxene crystals (Fig. 3e). Amphibole is the next phase to appear, although the rare $(<0.5 \mathrm{vol} \%)$ presence of plagioclase in hornblende-wehrlite NCX-06 suggests it can be accompanied by minor plagioclase crystallisation. The early stabilisation of amphibole is reflected by its high $\mathrm{Mg} \#$ (all $\mathrm{Fe}$ as $\mathrm{Fe}^{2+}$ ), which ranges from 73 in plagioclasehornblendites up to 83 in hornblende-wehrlite NCX-06. Such magnesian amphibole is not commonly found in arc phenocrysts or cumulates (e.g., in the well-studied Lesser Antilles arc cumulate suites; Stamper et al. 2014; Cooper et al. 2016), but has been observed in similar amphibolebearing ultramafic lithologies in exposed arc root complexes (e.g., Dessimoz et al. 2012; Bouilhol et al. 2015). Textural evidence indicates that amphibole forms through a peritectic reaction consuming clinopyroxene. This is particularly evident in the Type 3 hornblende-gabbro AAN-007 where 
Table 2 Overview of equilibrium mineral assemblages in the Nisyros samples compared with experimental studies at appropriate conditions that reproduce these assemblages

\begin{tabular}{lllllll}
\hline Group & Lithology & References & Composition & $T\left({ }^{\circ} \mathrm{C}\right)$ & $P(\mathrm{MPa})$ & $\mathrm{Melt} \mathrm{H}_{2} \mathrm{O}(\mathrm{wt} \%)$ \\
\hline Type 2 & (Hbl-)wehrlite & Melekhova et al. (2015) & Primitive basalt & $1150-1050$ & 700 & $3.0-10$ \\
& & Nandedkar et al. (2014) & Primitive basalt & $1150-1055$ & 700 & $3.0-4.0$ \\
Type 2-3 & (Hbl-)gabbro & Melekhova et al. (2015) & Primitive basalt & 1000 & 700 & 13.8 \\
& & Nandedkar et al. (2014) & Primitive basalt & 1040 & 700 & 4.9 \\
& & Blatter et al. (2013) & Mildly evolved basalt & $1100-1000$ & 700 & $2.6-4.2$ \\
& & Almeev et al. (2013) & Evolved basaltic andesite & 990 & 700 & $5.2-7.5$ \\
Type 3 & Pl-hornblendite & Nandedkar et al. (2014) & Primitive basalt & $1010-920$ & 700 & $6.2-8.5$ \\
& & Blatter et al. (2013) & Mildly evolved basalt & $975-950$ & 700 & $3.7-5.7$ \\
Enclaves & Pl-hornblendite & Pichavant et al. (2002) & Mildly evolved HAB & 950 & 400 & $6.8-6.9$ \\
Type 1 & (Hbl-)ol-gabbro & Sisson and Grove (1993) & Mildly evolved basalt & $1010-1000$ & 200 & Saturated \\
LPA suite & (Bas-)andesites & Grove et al. (2003) & Primitive HMA & $1030-1010$ & 200 & Saturated \\
& & Andújar et al. (2015) & Mildly evolved basalt & 1040 & $200-400$ & $2.8-7.3$ \\
& & Pichavant and Macdonald (2007) & Primitive basalt & $1090-1050$ & 400 & $3.2-3.9$
\end{tabular}

Experimental starting compositions are divided into primitive ( $\mathrm{Mg \#}>65)$, mildly evolved (Mg\# 65-55) and evolved $(\mathrm{Mg} \#<55)$

$H A B$ high-aluminium basalt, $H M A$ high-magnesium andesite. See Fig. 8 and text for further discussion

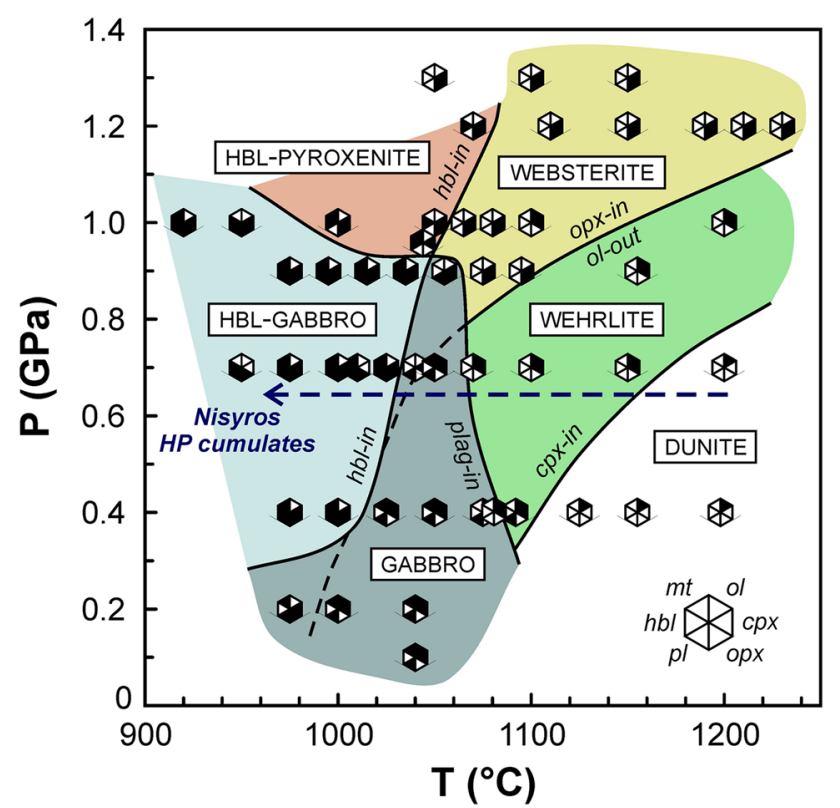

Fig. 10 Phase diagram for hydrous $\left(\geq 3 \mathrm{wt} \% \mathrm{H}_{2} \mathrm{O}\right.$ in starting material at $\mathrm{fO}_{2} \geq \mathrm{NNO}$ ) primitive arc magmas, modified after Melekhova et al. (2015) to include data from additional experimental studies (Müntener et al. 2001; Pichavant and Macdonald 2007; Blatter et al. 2013; Nandedkar et al. 2014; Andújar et al. 2015). The Nisyros Type 2 and 3 cumulates evolve from (hornblende-)wehrlites to hornblendegabbros and plagioclase-hornblendites, consistent with crystallisation at $0.5-0.8 \mathrm{GPa}$ (blue arrow). See text for further discussion

clinopyroxene is replaced by amphibole along rims, cracks and cleavage planes (Fig. 9a), similar to textures observed by Smith (2014). Plagioclase saturation is delayed and it first appears as a major crystallising phase in the hornblendegabbros where $\mathrm{An}_{77-80}$ plagioclase is in apparent equilibrium with relatively evolved, aluminous clinopyroxene $(\mathrm{Mg} \#$ 75-80, up to 9 wt\% $\mathrm{Al}_{2} \mathrm{O}_{3}$ ) and amphibole (Mg\# 73-76, up to $15 \mathrm{wt} \% \mathrm{Al}_{2} \mathrm{O}_{3}$ ). The suppression of plagioclase crystallisation is recorded by a marked increase in clinopyroxene $\mathrm{Al}_{2} \mathrm{O}_{3}$ content from $\sim 3 \mathrm{wt} \%$ at $\mathrm{Mg} \# 88$ to $9 \mathrm{wt} \% \mathrm{Al}_{2} \mathrm{O}_{3}$ at $\mathrm{Mg} \# 75$ (Fig. 8). Elevated $\mathrm{Al}_{2} \mathrm{O}_{3}$ contents reflect an increase in $\mathrm{Al}_{2} \mathrm{O}_{3} / \mathrm{SiO}_{2}$ of the residual melt and increased Ca-Tschermak's substitution in clinopyroxene in the absence of plagioclase fractionation (e.g., Müntener et al. 2001; Villiger et al. 2007). Upon plagioclase saturation, a decrease in clinopyroxene $\mathrm{Al}_{2} \mathrm{O}_{3}$ content would be expected. Clinopyroxene crystallisation, however, stops before the appearance of plagioclase and hence the plagioclase-in point is not recorded in clinopyroxene compositions. Amphibole crystallising together with plagioclase in Type 3 cumulates records near-constant $\mathrm{Al}_{2} \mathrm{O}_{3}$ contents over a range of $\mathrm{Mg \#}$ from 76 to $<70$ (Fig. 9).

The two key characteristics of the Type 2 and 3 cumulates are thus the early crystallisation of amphibole and the delayed appearance of plagioclase. The stability of amphibole and plagioclase in arc magmas is mainly a function of melt $\mathrm{H}_{2} \mathrm{O}$ content and pressure. Experimental studies addressing the differentiation of hydrous arc magmas at pressures ranging from 0.2 to $1.3 \mathrm{GPa}$ indicate that the stability of plagioclase is suppressed with increasing pressure and water content (Fig. 10; e.g., Sisson and Grove 1993; Müntener et al. 2001; Müntener and Ulmer 2006; Pichavant and 
Macdonald 2007; Nandedkar et al. 2014; Melekhova et al. 2015). In addition, these studies conclude that high pressure and water content favour the crystallisation of amphibole at higher temperature (earlier in the crystallisation sequence) and potentially before plagioclase. Specifically, crystallisation experiments of primitive arc magmas at a pressure of $0.7 \mathrm{GPa}$ and initial water content $\geq 3 \mathrm{wt} \%$ (Blatter et al. 2013; Nandedkar et al. 2014; Melekhova et al. 2015) reproduce the observed range of Type 2 and 3 cumulate lithologies (Fig. 10) as well as diagnostic compositional aspects such as the high $\mathrm{Al}_{2} \mathrm{O}_{3}$ content of clinopyroxene and high $\mathrm{Mg} \#$ and $\mathrm{Al}^{\mathrm{VI}}$ content of amphibole (Fig. 8). These studies find (hornblende-)wehrlite crystallisation at $1150-1050{ }^{\circ} \mathrm{C}$ while hornblende-gabbros and plagioclase-hornblendites progressively form from 1050 to $950{ }^{\circ} \mathrm{C}$ (Fig. 10). Although the total $\mathrm{Al}_{2} \mathrm{O}_{3}$ content of amphibole is mainly dependent on melt composition and temperature, $\mathrm{Al}^{\mathrm{VI}}$ content has a significant pressure dependency (e.g., Holloway and Burnham 1972; Putirka 2016). The combination of high $\mathrm{Al}^{\mathrm{VI}}$ and $\mathrm{Mg \#}$ in amphibole is diagnostic of crystallisation at lower crustal pressures $(0.7 \mathrm{GPa})$. Crystallisation experiments undertaken at lower pressure (0.2-0.4 GPa; Pichavant et al. 2002; Pichavant and Macdonald 2007; Andújar et al. 2015) invariable yield amphibole saturation at lower temperatures and after plagioclase, producing amphibole with lower $\mathrm{Mg \#}$ $(<70)$ and $\mathrm{Al}^{\mathrm{VI}}$ contents $<0.3$ apfu (Fig. 8).

On the basis of the convincing overlap with experimental assemblages, we conclude that the Nisyros Type 2 and 3 cumulates constitute a high-pressure (0.5-0.8 GPa) hydrous crystallisation trend. Such a trend is predicted by experimental studies (e.g., Nandedkar et al. 2014; Melekhova et al. 2015) and reported for exposed arc root complexes (e.g., Dessimoz et al. 2012; Bouilhol et al. 2015), but has not been previously found in arc cumulate suites. A pressure of 0.7 GPa equates to a depth of $25-30 \mathrm{~km}$, roughly the crustal thickness underneath Nisyros (e.g., Tirel et al. 2004). As such, the Type 2 and 3 cumulates provide a rare glimpse into a major magma differentiation level at the base of the crust that is not preserved in the erupted phenocrysts.

\section{Water-saturated shallow crystallisation}

The Type 1 cumulates are characterised by the association of calcic plagioclase $\left(>\mathrm{An}_{85}\right)$ with relatively evolved clinopyroxene (Mg\# 73-86, < $1000 \mathrm{ppm} \mathrm{Cr}$ ) and olivine $\left(\mathrm{Fo}_{70-82},<800 \mathrm{ppm} \mathrm{Ni}\right.$; Fig. 8). A similar assemblage is found in cumulates from the Lesser Antilles Arc where it is generally interpreted as the result of a two-stage crystallisation history (e.g., Arculus and Wills 1980; Tollan et al. 2012; Stamper et al. 2014; Cooper et al. 2016). The calcic composition of plagioclase reflects the suppression of plagioclase stability under hydrous conditions (e.g., Sisson and Grove 1993; Müntener et al. 2001; Pichavant and Macdonald 2007; Melekhova et al. 2015), whereas the abundance of plagioclase and relatively evolved composition of olivine and clinopyroxene in these cumulates suggests that they have crystallised from already differentiated, lower Mg\# mafic melts. In line with the interpretation of the Antilles cumulates, we therefore conclude that the Type 1 cumulates are the likely crystallisation products of hydrous, mildly evolved basaltic andesitic melts that underwent prior differentiation. It is probable that the mildly evolved character of these melts results from fractionation of the Type 2 and 3 cumulates in the lower arc crust. Upon ascent to shallow levels in the crust, the mildly evolved melts reach water saturation, thereby promoting the crystallisation of calcic plagioclase (e.g., Arculus and Wills 1980). This interpretation is supported by crystallisation experiments at 0.2 GPa using a mildly evolved (Mg\# 60) starting compositions under $\mathrm{H}_{2} \mathrm{O}$-saturated conditions (Sisson and Grove 1993) that reproduce the co-occurrence of high-An plagioclase and evolved olivine an clinopyroxene (grey plusses in Fig. 8). In addition, it agrees with the suggestion of Braschi et al. $(2012,2014)$ that mafic melts pond at the base of a (rhyo) dacitic mush reservoir in the upper crust, leading to crystallisation of Type 1 cumulate assemblages that can subsequently be entrained in HPRD host melts or enclaves. Textural relationships indicate that amphibole is a late crystallising phase in Type 1 cumulates and typically associated with the development of lower $\mathrm{An}$ rims $\left(\sim \mathrm{An}_{60}\right)$ in response to interaction with (host) melts, which is discussed in more detail below.

\section{Shallow level crystallisation of LPA suite phenocrysts}

There is a clear dichotomy between the early and late appearance of plagioclase in the LPA and HPRD suite, respectively. In contrast to the delayed plagioclase saturation seen in the Type 2 and 3 cumulates, textural and compositional evidence indicates that plagioclase is an early crystallising phase in the LPA suite. Plagioclase (up to $\mathrm{An}_{90}$ ) occurs as phenocrysts together with primitive clinopyroxene $(\mathrm{Mg \#}>85)$, which has $\mathrm{Eu} / \mathrm{Eu}^{*}<1$ in all but the most primitive crystals (see supplementary material) and low $\mathrm{Al}_{2} \mathrm{O}_{3}$ contents. Clinopyroxene in LPA basaltic andesites shows increasing $\mathrm{Al}_{2} \mathrm{O}_{3}$ content down to $\mathrm{Mg \#} \sim 86$. At this point, an inflection in the $\mathrm{Al}_{2} \mathrm{O}_{3}$ versus $\mathrm{Mg} \#$ trend marks the appearance of plagioclase as a crystallising phase (Fig. 8). Low-Al clinopyroxene is reproduced by fractional crystallisation experiments of high-Mg\# andesitic melts at upper crustal pressures (0.2 GPa; Grove et al. 2003), whereas experiments at higher pressures $(0.4-0.7 \mathrm{GPa})$ invariably produce more aluminous clinopyroxene (Fig. 8; Müntener et al. 2001; Pichavant and Macdonald 2007; Melekhova et al. 2015).

In contrast to the Type 1 cumulates, LPA suite phenocryst assemblages are characterised by lower plagioclase An\% at a 
given olivine composition and lower $\mathrm{CaO}$ contents in clinopyroxene (Fig. 8). These characteristics likely result from a combination of lower pressure, and possibly higher temperature and lower water contents, compared to the cumulate assemblages in the HPRD suite. A comparison with experimentally produced phenocryst assemblages suggests that the LPA phenocrysts crystallised from hydrous melts $\left(2-4 \mathrm{wt} \% \mathrm{H}_{2} \mathrm{O}\right)$ in the upper crust $(0.2-0.4 \mathrm{GPa})$. Anhydrous crystallisation experiments produce more Na-rich plagioclase (Fig. 8; Almeev et al. 2013) which is at odds with the observed plagioclase compositions and the appearance of amphibole in the LPA dacites. High whole rock and clinopyroxene phenocryst $\mathrm{Mg \#} \mathrm{(up} \mathrm{to} 68$ and 91, respectively) suggest that the LPA basaltic andesites represent relatively primitive melts. The absence of systematic trace element or isotopic differences compared to mafic enclaves in the HPRD suite (Klaver et al. 2016) effectively rules out that the LPA suite derives from compositionally distinct or less hydrous primary melts than those from which the Type 2 and 3 cumulates crystallised in the lower crust. Hence, we propose that the dichotomy in mineral assemblages and compositions between the LPA and HPRD suites predominantly reflects depth of crystallisation. Whereas the HPRD suite records crystallisation at the base of the crust, the LPA suite appears to have differentiated from relatively primitive (high $\mathrm{Mg \# )} \mathrm{melts} \mathrm{that} \mathrm{were} \mathrm{injected} \mathrm{into} \mathrm{mid-} \mathrm{to} \mathrm{upper} \mathrm{crustal}$ reservoirs without pronounced modification at the base of the crust.

\section{A deep or shallow amphibole sponge?}

Whole rock data of global arc lavas suggest that amphibole is a common, but often cryptic, phase in the differentiation of arc magmas (e.g., Davidson et al. 2007). Although studies of arc root complexes (e.g., Dessimoz et al. 2012; Bouilhol et al. 2015) and arc cumulates (e.g., Smith 2014; Cooper et al. 2016) have established that amphibole forms through a peritectic reaction consuming clinopyroxene, it is still unclear at which level in the volcanic plumbing system this "amphibole sponge" exerts the strongest control on melt compositions. Nisyros amphibole can be roughly divided into three groups based on its composition: (1) amphibole phenocrysts in the LPA dacites, (2) late-stage, interstitial amphibole in Type 1 cumulates and (3) peritectic amphibole in Type 2 and 3 cumulates. Phenocrysts in the LPA dacites match amphibole crystallising from andesitic to dacitic liquids at $0.2 \mathrm{GPa}$ and $>6 \mathrm{wt} \% \mathrm{H}_{2} \mathrm{O}$ in the melt (Andújar et al. 2016) and are in equilibrium with their host melt. Therefore, they do not represent reaction-replacement amphibole and are not considered further here.

Textural evidence suggests that amphibole has formed through the reaction of clinopyroxene with primitive melts in Type 2 and 3 cumulates, which is supported by high Mg\#, low trace element contents and a lack of Eu-anomalies in these amphiboles (Fig. 6). Amphibole in these cumulates displays a progressive crystallisation trend with slightly increasing tetrahedral $\mathrm{Al}\left(\mathrm{Al}^{\mathrm{IV}}\right)$ and $\mathrm{TiO}_{2}$ contents and decreasing $\mathrm{Mg} \#$ from Type 2 to Type 3 cumulates. A similar trend is present in core-to-rim traverses of euhedral amphibole in hornblende-gabbro AAN-007 (Figs. 9, 11). Entrainment of this cumulate nodule in a rhyolitic melt caused the

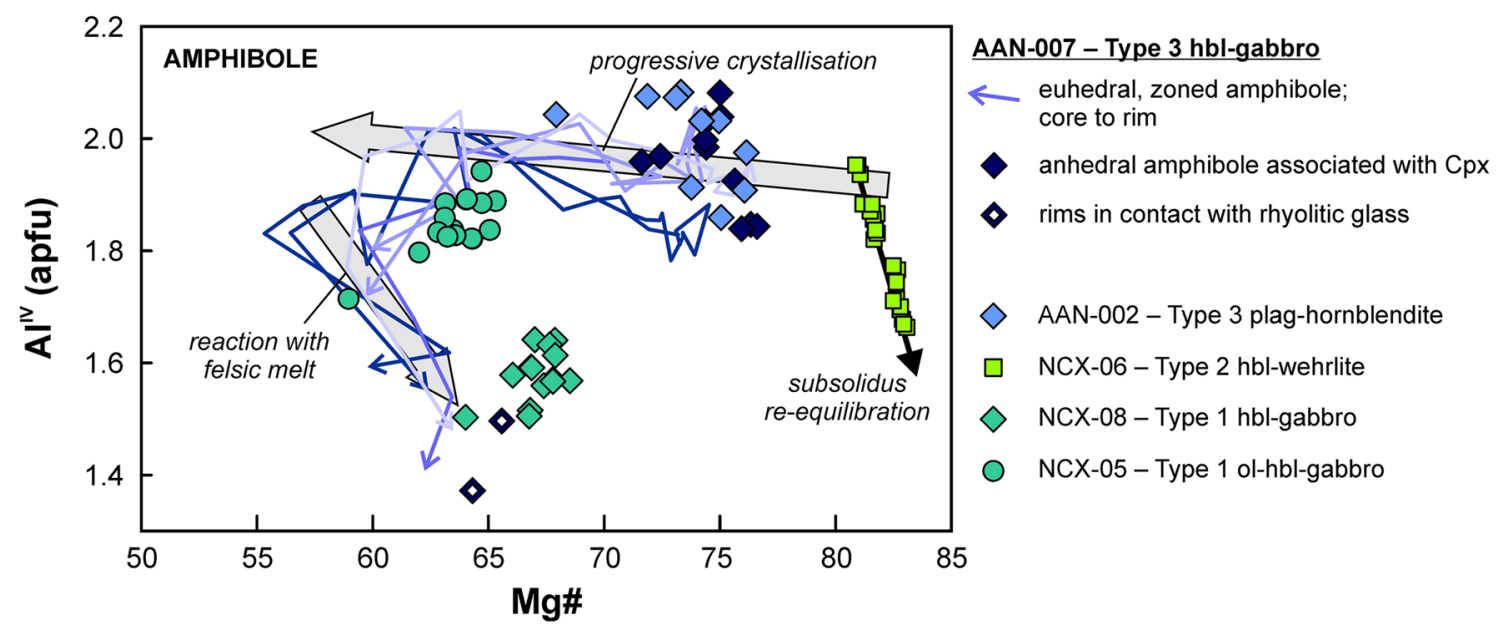

Fig. 11 Diagram of $\mathrm{Al}^{\mathrm{IV}}$ versus $\mathrm{Mg} \#$ for amphibole in the cumulates. Amphibole in the Type 2 hornblende-wehrlite (NCX-06) displays a well-defined linear trend along a Mg-Tschermak's substitution vector that results from subsolidus re-equilibration during cooling (Ernst and Liu 1998; Dessimoz et al. 2012). The Type 3 cumulates display a small core-to-rim increase in amphibole $\mathrm{Al}^{\mathrm{IV}}$ with decreasing $\mathrm{Mg \#}$ that is consistent with progressive crystallisation. Reaction with a felsic melt leads to resorption, decreasing $\mathrm{Al}^{\mathrm{IV}}$ and a small increase in $\mathrm{Mg \# .} \mathrm{See} \mathrm{text} \mathrm{for} \mathrm{further} \mathrm{discussion}$ 
pronounced disequilibrium in the amphibole crystals, as indicated by a marked decrease in $\mathrm{Mg} \#, \mathrm{TiO}_{2}, \mathrm{Na}_{2} \mathrm{O}$ and $\mathrm{Al}^{\mathrm{IV}}$ contents in the resorbed rims (Fig. 9). Interestingly, $\mathrm{Mg} \#$ increases again in the outermost rims of the resorbed crystals. The resorbed rims of AAN-007 have similar low $\mathrm{Al}^{\mathrm{IV}}$ content and $\mathrm{Mg} \#$ as interstitial amphibole in Type 1 cumulates (Fig. 11). The latter has an enriched trace element composition, including negative Eu-anomalies and high $\mathrm{La} /$ $\mathrm{Yb}$ and Ba contents (Fig. 6), as also found by Smith (2014) and Cooper et al. (2016) for interstitial amphibole in similar arc cumulate nodules. Such amphibole compositions have not been reproduced in crystallisation experiments and hence suggest growth in response to interaction with an infiltrating melt rather than equilibrium crystallisation. A common process of reaction with an evolved, hydrous melt is, therefore, evoked for the crystallisation of the low $\mathrm{Al}^{\mathrm{IV}}$ amphiboles in Type 1 cumulates and the resorbed rims of AAN-007 (Smith 2014). In addition, the low $\mathrm{Al}^{\mathrm{VI}}$ contents of interstitial amphibole (Fig. 8) corroborate our conclusion that the Type 1 cumulates crystallised at shallow crustal levels.

The peritectic reaction in which amphibole forms at the expense of clinopyroxene is instrumental in driving derivative melts to andesitic-rhyolitic calc-alkaline compositions over a relatively short crystallisation interval (e.g., Holloway and Burnham 1972; Cawthorn and O'Hara 1976; Davidson et al. 2007). We find evidence for the crystallisation of amphibole at different crustal levels and under different conditions. Although the infiltration of a felsic melt in Type 1 cumulates at shallow levels can lead to the crystallisation of interstitial amphibole, we propose that this process is volumetrically insignificant and cannot account for the important role of amphibole in generating calc-alkaline differentiation trends. The Type 2 and 3 cumulates, on the other hand, record early stabilisation of amphibole in equilibrium with mafic melts and experimental studies demonstrate that amphibole will continue to crystallise over a large temperature interval (e.g., Nandedkar et al. 2014). A detailed assessment of the role of amphibole in generating the (rhyo)dacites on Nisyros is outside the scope of this work. We do note, however, the striking resemblance in lithology between the Type 3 cumulates and the hornblende-gabbroic assemblage found to be in equilibrium with Mount St. Helens dacites (Blatter et al. 2017). This study demonstrates that porphyritic dacites, compositionally and texturally similar to the Nisyros HPRD suite, are multiply saturated in plagioclase, pyroxene, amphibole and magnetite at $0.7 \mathrm{GPa}$ and form along a peritectic reaction involving amphibole and clinopyroxene. Hence, we tentatively propose that the lower crustal Type 3 cumulates can be complementary to the Nisyros HPRD suite magmas.

\section{Synthesis: structure of Nisyros' plumbing system}

Our interpretation of the structure of Nisyros' volcanic plumbing system based on the petrology and composition of cumulates and phenocrysts is shown schematically in Fig. 12. This model is in general agreement with ideas proposed by Wyers and Barton (1989) and Seymour and Vlassopoulos (1992), but provides further refinement and, for the first time, documents the importance of differentiation at the base of the arc crust. We interpret the Type 2 cumulates with Al-rich clinopyroxene as the most primitive cumulate assemblage found in the HPRD suite. Derivative melts formed by the fractionation of Type 2 cumulates will have lower $\mathrm{Mg} \#$ and higher $\mathrm{H}_{2} \mathrm{O}$ contents than primitive melts and will, upon ascent and water saturation, crystallise the common Type 1 cumulates. In the lower crust, Type 2 cumulates will mature to Type 3 hornblende-gabbros and plagioclase-hornblendites along a peritectic reaction in which clinopyroxene is consumed and amphibole and dacitic melt are generated (e.g., Blatter et al. 2017). The latter is a prime candidate to feed a shallow (rhyo)dacitic mush system that, upon reactivation by mafic melts, can be erupted as porphyritic, enclave-bearing domes and lava flows of the HPRD suite (this study; Braschi et al. 2012, 2014; Zouzias and St Seymour 2014). As such, we infer that differentiation of the HPRD suite is predominantly controlled by cumulate-melt reaction processes in the lower crust, but that most of their textural features are obtained through shallow crystallisation and mixing processes.

The LPA suite, on the other hand, does not show evidence for protracted differentiation in the lower crust. Textural and chemical evidence indicates that plagioclase is an early crystallising phase and in equilibrium with very primitive (Mg\# up to 91) clinopyroxene. Thus, the LPA (basaltic) andesites appear to have differentiated from primitive melts predominantly at shallow crustal levels. Given the lack of hybridisation between the LPA and HPRD suites, we argue that the two suites evolved in isolated parts of the volcanic plumbing system. Although there is a gradual change from LPA-dominated to HPRD-dominated magmatism with time, LPA andesites and basaltic andesites have also been emplaced during the caldera-forming stage (Fig. 1) without any associated major changes in HPRD suite petrography. In addition, the eccentric activity stage is characterised by rapid and repeated switching between eruption of HPRD dacites and LPA basaltic andesites as seen in unit PA (Lies tuff cone; Fig. 1). These lines of evidence contradict the assertion that the LPA and HPRD suites can be accommodated in a single shallow reservoir through gradual differentiation with time, as for instance proposed by Francalanci et al. (1995). 
Fig. 12 Schematic cross-section illustrating the relationship between the different cumulate and phenocryst suites found on Nisyros. The HPRD suite preserves evidence for differentiation at the base of the arc crust where the reaction of wehrlitic (Type 2) cumulates with hydrous melts stabilises amphibole to form the Type 3 cumulates. Type 1 cumulates, however, crystallise from already differentiated melts at shallower levels in the plumbing system, likely at the base of a shallow mush system where the HPRD host lavas acquire their textural features. In contrast, the LPA suite does not show evidence for protracted modification at the base of the arc crust and differentiated from high-Mg\# melts at shallow levels. There is no evidence for interaction between the two suites in their crystal records

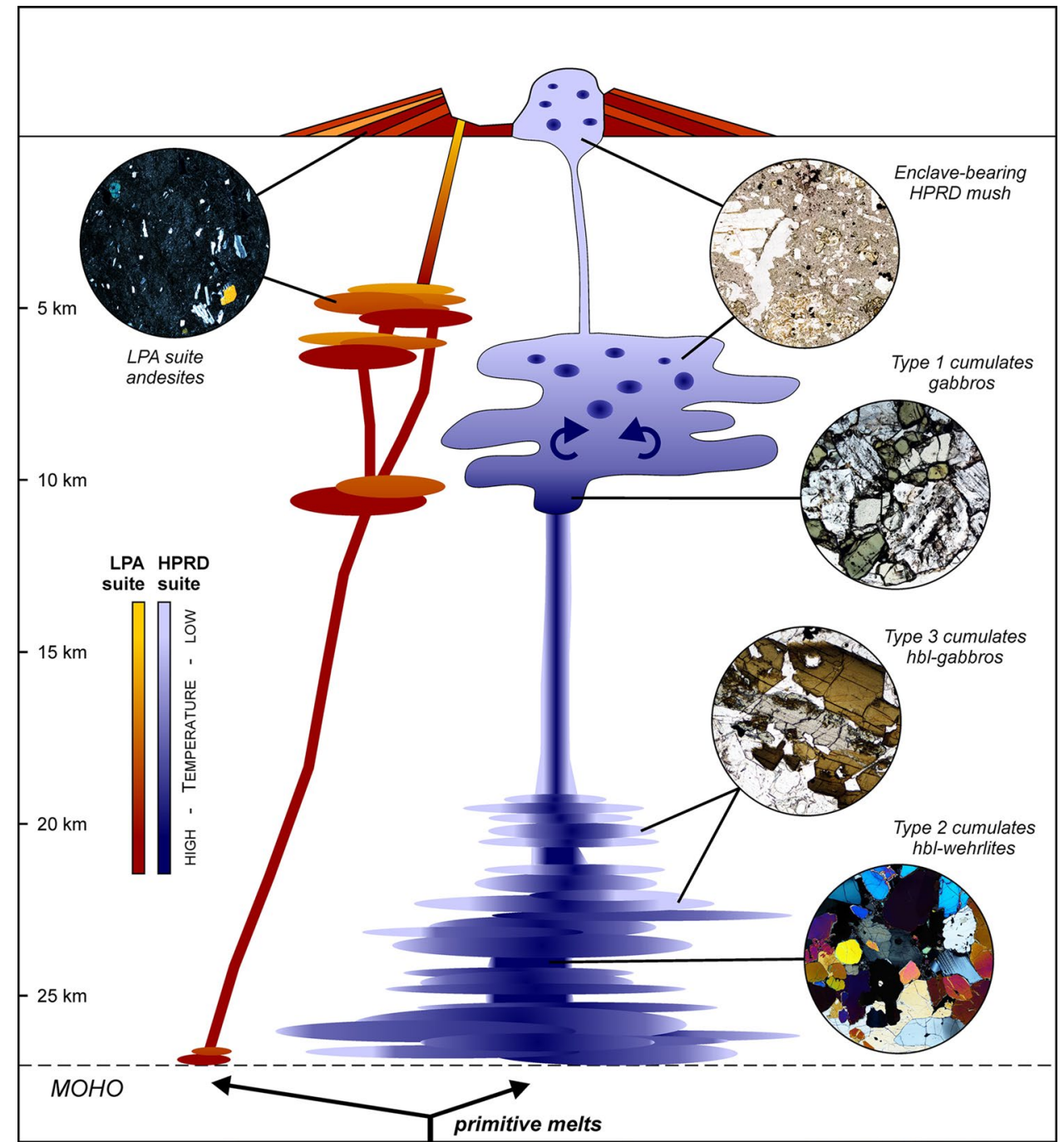

\section{Implications for island arc magmatism}

One of the implications of this study is that the HPRD (rhyo)dacites could be generated through a peritectic reaction at the base of the Nisyros arc crust as recorded in the Type 3 cumulates. In contrast, they acquire their petrographic features through crystallisation and mixing in a mush system in the mid- to upper crust. Hence, Nisyros is in good agreement with the notion of Annen et al. (2006) that significant decoupling between the geochemical and petrographic characteristics of arc magmas is probably the norm rather than the exception in volcanic rocks in arcs built on (thinned) continental crust. Whereas differentiation in the lower arc crust can exert a dominant control on the geochemical composition of the magmas (e.g., Hildreth and Moorbath 1988; Davidson et al. 2007), textural and petrographic aspects are predominantly obtained during shallow storage (e.g., Eichelberger 1978; Annen et al. 2006; Bachmann and Huber 2016). This provides an elegant solution to the common misfit between observed phenocryst phases and cumulate assemblages in arc lavas and the fractionating mineral assemblages required to reproduce whole rock major element variations in arc suites (e.g., Annen et al. 2006; Melekhova et al. 2015). Type 1 cumulates, the products of shallow crystallisation of evolved melts at water saturation, dominate in arc cumulate suites (e.g., Arculus and Wills 1980; Tollan et al. 2012; Cooper et al. 2016). Together with phenocryst assemblages, such cumulates rarely reflect the early stages of magmatic differentiation in the lower arc crust (e.g., Arculus and Wills 1980; Tollan et al. 2012). Moreover, many arc suites have a geochemical signature of phases that are stable at pressures pertinent to the lower crust but are scarcely present as phenocryst phases, such as amphibole (e.g., Davidson et al. 2007) and garnet (e.g., Macpherson et al. 2006; Alonso-Perez et al. 2009). The Nisyros Type 2 and 3 cumulates, however, provide a rare insight into differentiation of primitive, hydrous melts 
at lower crustal conditions in arcs. The replacement of clinopyroxene by amphibole in these cumulates provides direct evidence for the fundamental importance of amphibole fractionation in generating evolved melts (e.g., Holloway and Burnham 1972; Cawthorn and O'Hara 1976), consistent with textural evidence from arc root complexes (e.g., Dessimoz et al. 2012; Bouilhol et al. 2015). Whether amphibole is actually present as a phenocryst phase in these evolved rocks depends on the $P-T-\mathrm{pH}_{2} \mathrm{O}$ conditions in the shallow storage region and does not reflect differentiation in a deep crustal hot zone.

\section{Conclusions}

This study reports petrographic descriptions and mineral major and trace element data of lavas, pyroclastic rocks, enclaves and cumulates from Nisyros volcano, Greece. We propose a new division of the Nisyros volcanic rocks into a low-porphyricity andesite (LPA) and high-porphyricity (rhyo)dacite (HPRD) suite, which have evolved along distinct petrogenetic pathways and show no evidence for hybridisation. The preservation of primitive, lower crustal cumulate fragments in the HPRD suite provide a glimpse of the earliest stages of magma differentiation in arcs. The main conclusions that can be drawn from this study are:

1. Type 2 and 3 cumulates define a continuum from (hornblende-)wehrlites to plagioclase-hornblendites that form a striking resemblance to the products of fractionation experiments of hydrous primitive melts at lower crustal (0.7 GPa) pressures and to exposed arc root complexes.

2. Clinopyroxene $\mathrm{Al}_{2} \mathrm{O}_{3}$ contents can be used in tandem with textural relationships to infer the timing of plagioclase saturation: clinopyroxene phenocrysts in the LPA suite have low $\mathrm{Al}_{2} \mathrm{O}_{3}$ contents, consistent with early plagioclase saturation at low pressure, whereas clinopyroxene in the Type 2 and 3 cumulates shows $\mathrm{Al}_{2} \mathrm{O}_{3}$ contents up to $9 \mathrm{wt} \%$ due to the suppression of plagioclase crystallisation.

3. Reaction of the wehrlitic Type 2 cumulates with a primitive, hydrous melt leads to the formation of amphibole at the expense of clinopyroxene to form Type 3 cumulates, a key reaction in producing (rhyo)dacitic derivative melts. The major and trace element composition of amphibole in these cumulates confirms crystallisation at high pressure $(\sim 0.7 \mathrm{GPa})$, in contrast to late-stage interstitial amphibole in Type 1 cumulates.

4. The most common cumulates in the HPRD suite are plagioclase-clinopyroxene-olivine Type 1 cumulates. Anorthite-rich plagioclase in combination with low-Mg\# clinopyroxene and olivine attest to crystallisation from an already mildly evolved melt at upper crustal pressures and water saturated conditions. Hence, the Type 1 cumulates are not complementary to the (rhyo)dacites in which they are hosted, but rather an accumulation of phenocrysts from a mildly evolved melt in a shallow reservoir.

Acknowledgements Permission for fieldwork and sampling on Nisyros was kindly provided by the Greek Institute for Geology and Mineral Exploration. Bouke Lacet and Wynanda Koot were invaluable in turning kgs of rock into polished thin sections. Quint van den Heuvel, Aryen Bhagirath, Eva van der Voet and Wilmer Roest are greatly acknowledged for carrying out part of the EMP analyses as part of their BSc thesis projects at the Vrije Universiteit Amsterdam. Ben Buse is thanked for help with the EMP analyses in Bristol. Discussions with Manfred van Bergen, Othmar Müntener and Jon Blundy contributed to the interpretation of the data. Constructive comments by Loyc Vanderkluysen, two anonymous reviewers and editor Othmar Müntener significantly helped to improve the manuscript.

Open Access This article is distributed under the terms of the Creative Commons Attribution 4.0 International License (http://creativecommons.org/licenses/by/4.0/), which permits unrestricted use, distribution, and reproduction in any medium, provided you give appropriate credit to the original author(s) and the source, provide a link to the Creative Commons license, and indicate if changes were made.

\section{References}

Almeev RR, Holtz F, Ariskin AA, Kimura J-I (2013) Storage conditions of Bezymianny Volcano parental magmas: results of phase equilibria experiments at 100 and $700 \mathrm{MPa}$. Contrib Mineral Petrol 166:1389-1414

Alonso-Perez R, Müntener O, Ulmer P (2009) Igneous garnet and amphibole fractionation in the roots of island arcs: experimental constraints on andesitic liquids. Contrib Mineral Petrol 157:541-558

Andújar J, Scaillet B, Pichavant M, Druitt TH (2015) Differentiation conditions of a basaltic magma from Santorini, and its bearing on the production of andesite in arc settings. J Petrol 56:765-794

Andújar J, Scaillet B, Pichavant M, Druitt TH (2016) Generation conditions of dacite and rhyodacite via the crystallization of an andesitic magma. Implications for the plumbing system at Santorini (Greece) and the origin of tholeiitic or calc-alkaline differentiation trends in arc magmas. J Petrol 57:1887-1920

Annen C, Blundy J, Sparks R (2006) The genesis of intermediate and silicic magmas in deep crustal hot zones. J Petrol 47:505-539

Arculus RJ, Wills KJ (1980) The petrology of plutonic blocks and inclusions from the Lesser Antilles island arc. J Petrol 21:743-799

Bachmann O, Huber C (2016) Silicic magma reservoirs in the Earth's crust. Am Mineral 101:2377-2404

Bachmann O, Charlier B, Lowenstern J (2007) Zircon crystallization and recycling in the magma chamber of the rhyolitic Kos Plateau Tuff (Aegean arc). Geology 35:73-76

Bachmann O, Deering CD, Ruprecht JS, Huber C, Skopelitis A, Schnyder C (2012) Evolution of silicic magmas in the Kos-Nisyros volcanic center, Greece: a petrological cycle associated with caldera collapse. Contrib Mineral Petrol 163:151-166

Bacon CR (1986) Magmatic inclusions in silicic and intermediate volcanic rocks. J Geophys Res 91:6091-6112 
Bergantz G, Schleicher J, Burgisser A (2015) Open-system dynamics and mixing in magma mushes. Nat Geosci 8:793-796

Blatter DL, Sisson TW, Hankins WB (2013) Crystallization of oxidized, moderately hydrous arc basalt at mid-to lower-crustal pressures: implications for andesite genesis. Contrib Mineral Petrol 166:861-886

Blatter DL, Sisson TW, Hankins WB (2017) Voluminous arc dacites as amphibole reaction-boundary liquids. Contrib Mineral Petrol 172:27

Blum-Oeste M, Wörner G (2016) Central Andean magmatism can be constrained by three ubiquitous end-members. Terra Nova 28:434-440

Blundy J, Cashman K (2005) Rapid decompression-driven crystallization recorded by melt inclusions from Mount St. Helens volcano. Geology 33:793-796

Blundy J, Cashman K (2008) Petrologic reconstruction of magmatic system variables and processes. Rev Mineral Geochem 69:179-239

Bouilhol P, Schmidt M, Burg J-P (2015) Magma transfer and evolution in channels within the arc crust: the pyroxenitic feeder pipes of Sapat (Kohistan, Pakistan). J Petrol 56:1309-1342

Braschi E, Francalanci L, Vougioukalakis GE (2012) Inverse differentiation pathway by multiple mafic magma refilling in the last magmatic activity of Nisyros Volcano, Greece. Bull Volcanol 74:1083-1100

Braschi E, Francalanci L, Tommasini S, Vougioukalakis GE (2014) Unraveling the hidden origin and migration of plagioclase phenocrysts by in situ $\mathrm{Sr}$ isotopes: the case of final dome activity at Nisyros volcano, Greece. Contrib Mineral Petrol 167:1-25

Buettner A, Kleinhanns IC, Rufer D, Hunziker JC, Villa IM (2005) Magma generation at the easternmost section of the Hellenic arc: $\mathrm{Hf}, \mathrm{Nd}, \mathrm{Pb}$ and $\mathrm{Sr}$ isotope geochemistry of Nisyros and Yali volcanoes (Greece). Lithos 83:29-46

Cawthorn RG, O'Hara M (1976) Amphibole fractionation in calcalkaline magma genesis. Am J Sci 276:309-329

Coombs ML, Sisson TW, Bleick HA, Henton SM, Nye CJ, Payne AL, Cameron CE, Larsen JF, Wallace KL, Bull KF (2013) Andesites of the 2009 eruption of Redoubt Volcano, Alaska. J Volcanol Geotherm Res 259:349-372

Cooper KM, Kent AJ (2014) Rapid remobilization of magmatic crystals kept in cold storage. Nature 506:480-483

Cooper GF, Davidson JP, Blundy JD (2016) Plutonic xenoliths from Martinique, Lesser Antilles: evidence for open system processes and reactive melt flow in island arc crust. Contrib Mineral Petrol 171:87

Costa F, Dungan M (2005) Short time scales of magmatic assimilation from diffusion modeling of multiple elements in olivine. Geology 33:837-840

Davidson JP, Hora JM, Garrison JM, Dungan MA (2005) Crustal forensics in arc magmas. J Volcanol Geotherm Res 140:157-170

Davidson J, Turner S, Handley H, Macpherson C, Dosseto A (2007) Amphibole "sponge" in arc crust? Geology 35:787-790

Dessimoz M, Müntener O, Ulmer P (2012) A case for hornblende dominated fractionation of arc magmas: the Chelan Complex (Washington Cascades). Contrib Mineral Petrol 163:567-589

Di Paola G (1974) Volcanology and petrology of Nisyros island (Dodecanese, Greece). Bull Volcanol 38:944-987

Eichelberger J (1978) Andesitic volcanism and crustal evolution. Nature 275:21-27

Erdmann S, Martel C, Pichavant M, Kushnir A (2014) Amphibole as an archivist of magmatic crystallization conditions: problems, potential, and implications for inferring magma storage prior to the paroxysmal 2010 eruption of Mount Merapi, Indonesia. Contrib Mineral Petrol 167:1-23

Ernst W, Liu J (1998) Experimental phase-equilibrium study of Aland Ti-contents of calcic amphibole in MORB - a semiquantitative thermobarometer. Am Mineral 83:952-969
Francalanci L, Varekamp J, Vougioukalakis G, Delant M, Innocenti F, Manetti P (1995) Crystal retention, fractionation and crustal assimilation in a convecting magma chamber, Nisyros Volcano, Greece. Bull Volcanol 56:601-620

Ginibre C, Wörner G, Kronz A (2007) Crystal zoning as an archive for magma evolution. Elements 3:261-266

Griffin W, Powell W, Pearson N, O'Reilly S (2008) GLITTER: data reduction software for laser ablation ICP-MS. Laser ablationICP-MS in the earth sciences mineralogical association of Canada short course series 40:204-207

Grove TL, Elkins-Tanton LT, Parman SW, Chatterjee N, Müntener O, Gaetani GA (2003) Fractional crystallization and mantlemelting controls on calc-alkaline differentiation trends. Contrib Mineral Petrol 145:515-533

Hildreth W, Moorbath S (1988) Crustal contributions to arc magmatism in the Andes of central Chile. Contrib Mineral Petrol 98:455-489

Holloway JR, Burnham CW (1972) Melting relations of basalt with equilibrium water pressure less than total pressure. J Petrol 13:1-29

Humphreys MC, Christopher T, Hards V (2009) Microlite transfer by disaggregation of mafic inclusions following magma mixing at Soufrière Hills volcano, Montserrat. Contrib Mineral Petrol 157:609-624

Irvine T (1982) Terminology for layered intrusions. J Petrol 23:127-162

Jagoutz O, Müntener O, Ulmer P, Pettke T, Burg J-P, Dawood H, Hussain S (2007) Petrology and mineral chemistry of lower crustal intrusions: the Chilas Complex, Kohistan (NW Pakistan). J Petrol 48:1895-1953

Kelemen P, Hanghøj K, Greene A (2003) One view of the geochemistry of subduction-related magmatic arcs, with an emphasis on primitive andesite and lower crust. Treatise Geochem 3:593-659

Keller J (1971) The major volcanic events in recent eastern mediterranean volcanism and their bearing on the problem of Santorini ash layers. First Int Sci Congr Volcano Thera Greece 1969(1):151-169

Kent AJ (2014) Preferential eruption of andesitic magmas: implications for volcanic magma fluxes at convergent margins. Geol Soc Lond Spec Publ 385:257-280

Kiss B, Harangi S, Ntaflos T, Mason PR, Pál-Molnár E (2014) Amphibole perspective to unravel pre-eruptive processes and conditions in volcanic plumbing systems beneath intermediate arc volcanoes: a case study from Ciomadul volcano (SE Carpathians). Contrib Mineral Petrol 167:1-27

Klaver M, Davies GR, Vroon PZ (2016) Subslab mantle of African provenance infiltrating the Aegean mantle wedge. Geology 44:367-370

Le Maitre RW, Bateman P, Dudek A, Keller J, Lameyre J, Le Bas M, Sabine P, Schmid R, Sorensen H, Streckeisen A (1989) A classification of igneous rocks and glossary of terms: recommendations of the international union of geological sciences subcommission on the systematics of igneous rocks. Blackwell, Oxford

Leake BE, Woolley AR, Arps CE, Birch WD, Gilbert MC, Grice JD, Hawthorne FC, Kato A, Kisch HJ, Krivovichev VG (1997) Nomenclature of amphiboles: report of the subcommittee on amphiboles of the international mineralogical association commission on new minerals and mineral names. Mineral Mag 61:295-321

Limburg EM, Varekamp JC (1991) Young pumice deposits on Nisyros, Greece. Bull Volcanol 54:68-77

Longchamp C, Bonadonna C, Bachmann O, Skopelitis A (2011) Characterization of tephra deposits with limited exposure: the example of the two largest explosive eruptions at Nisyros volcano (Greece). Bull Volcanol 73:1337-1352

Macpherson CG, Dreher ST, Thirlwall MF (2006) Adakites without slab melting: high pressure differentiation of island arc magma, Mindanao, the Philippines. Earth Planet Sci Lett 243:581-593 
Martin VM, Morgan DJ, Jerram DA, Caddick MJ, Prior DJ, Davidson JP (2008) Bang! Month-scale eruption triggering at Santorini volcano. Science 321:1178

McDonough WF, Sun SS (1995) The composition of the Earth. Chem Geol 120:223-253

Melekhova E, Blundy J, Robertson R, Humphreys MC (2015) Experimental evidence for polybaric differentiation of primitive arc basalt beneath St. Vincent, Lesser Antilles. J Petrol 56:161-192

Müntener O, Ulmer P (2006) Experimentally derived high-pressure cumulates from hydrous arc magmas and consequences for the seismic velocity structure of lower arc crust. Geophys Res Lett 33:L21308

Müntener O, Kelemen PB, Grove TL (2001) The role of $\mathrm{H}_{2} \mathrm{O}$ during crystallization of primitive arc magmas under uppermost mantle conditions and genesis of igneous pyroxenites: an experimental study. Contrib Mineral Petrol 141:643-658

Nandedkar RH, Ulmer P, Müntener O (2014) Fractional crystallization of primitive, hydrous arc magmas: an experimental study at 0.7 GPa. Contrib Mineral Petrol 167:1-27

Parmigiani A, Huber C, Bachmann O (2014) Mush microphysics and the reactivation of crystal-rich magma reservoirs. J Geophys Res 119:6308-6322

Pe-Piper G, Moulton B (2008) Magma evolution in the PliocenePleistocene succession of Kos, South Aegean arc (Greece). Lithos 106:110-124

Pichavant M, Macdonald R (2007) Crystallization of primitive basaltic magmas at crustal pressures and genesis of the calc-alkaline igneous suite: experimental evidence from St Vincent, Lesser Antilles arc. Contrib Mineral Petrol 154:535-558

Pichavant M, Martel C, Bourdier JL, Scaillet B (2002) Physical conditions, structure, and dynamics of a zoned magma chamber: Mount Pelée (Martinique, Lesser Antilles Arc). J Geophys Res 107:2093

Putirka K (2016) Amphibole thermometers and barometers for igneous systems and some implications for eruption mechanisms of felsic magmas at arc volcanoes. Am Mineral 101:841-858

Reubi O, Blundy J (2009) A dearth of intermediate melts at subduction zone volcanoes and the petrogenesis of arc andesites. Nature 461:1269-1273

Ridolfi F, Renzulli A, Puerini M (2010) Stability and chemical equilibrium of amphibole in calc-alkaline magmas: an overview, new thermobarometric formulations and application to subductionrelated volcanoes. Contrib Mineral Petrol 160:45-66

Roeder P, Emslie R (1970) Olivine-liquid equilibrium. Contrib Mineral Petrol 29:275-289

Seymour KS, Vlassopoulos D (1992) Magma mixing at Nisyros volcano, as inferred from incompatible trace-element systematics. J Volcanol Geotherm Res 50:273-299

Sisson T, Grove T (1993) Experimental investigations of the role of $\mathrm{H}_{2} \mathrm{O}$ in calc-alkaline differentiation and subduction zone magmatism. Contrib Mineral Petrol 113:143-166

Smith DJ (2014) Clinopyroxene precursors to amphibole sponge in arc crust. Nat Commun. doi:10.1038/ncomms5329

Smith P, York D, Chen Y, Evensen N (1996) Single crystal 40Ar39Ar dating of a Late Quaternary paroxysm on Kos, Greece: concordance of terrestrial and marine ages. Geophys Res Lett 23:3047-3050
Spandler C, Martin LH, Pettke T (2012) Carbonate assimilation during magma evolution at Nisyros (Greece), South Aegean Arc: evidence from clinopyroxenite xenoliths. Lithos 146:18-33

Stamper C, Blundy J, Arculus R, Melekhova E (2014) Petrology of plutonic xenoliths and volcanic rocks from Grenada, Lesser Antilles. J Petrol 55:1353-1387

Streck MJ (2008) Mineral textures and zoning as evidence for open system processes. Rev Mineral Geochem 69:595-622

Tirel C, Gueydan F, Tiberi C, Brun J-P (2004) Aegean crustal thickness inferred from gravity inversion. Geodynamical implications. Earth Planet Sci Lett 228:267-280

Tollan P, Bindeman I, Blundy J (2012) Cumulate xenoliths from St. Vincent, Lesser Antilles Island Arc: a window into upper crustal differentiation of mantle-derived basalts. Contrib Mineral Petrol 163:189-208

Turner S, Costa F (2007) Measuring timescales of magmatic evolution. Elements 3:267-272

Vanderkluysen L, Volentik A, Hernandez J, Hunziker JC, Bussy F, Principe $C$ (2005a) The petrology and geochemistry of lavas and tephras of Nisyros Volcano (Greece). In: Hunziker JC, Marini L (eds) The geology, geochemistry and evolution of Nisyros Volcano (Greece). Implications for the volcanic hazards, vol 44. Mémoires de Géologie, Lausanne, pp 79-99

Vanderkluysen L, Volentik A, Principe C, Hunziker JC, Hernandez J (2005b) Nisyros' volcanic evolution: the growth of a strato-volcano. In: Hunziker JC, Marini L (eds) The geology, geochemistry and evolution of Nisyros Volcano (Greece). Implications for the volcanic hazards, vol 44. Mémoires de Géologie, Lausanne, pp $100-106$

Villiger S, Ulmer P, Müntener O (2007) Equilibrium and fractional crystallization experiments at $0.7 \mathrm{GPa}$; the effect of pressure on phase relations and liquid compositions of tholeiitic magmas. $\mathbf{J}$ Petrol 48:159-184

Volentik A, Vanderkluysen L, Principe C, Hunziker JC (2005a) Stratigraphy of Nisyros Volcano (Greece). In: Hunziker JC, Marini L (eds) The geology, geochemistry and evolution of Nisyros Volcano (Greece) implications for the volcanic hazards, vol 44. Mémoires de Géologie, Lausanne, pp 26-66

Volentik A, Principe C, Vanderkluysen L, Hunziker JC (2005b) Explanatory notes on the "geological map of Nisyros Volcano (Greece)". In: Hunziker JC, Marini L (eds) The geology, geochemistry and evolution of Nisyros Volcano (Greece) implications for the volcanic hazards, vol 44. Mémoires de Géologie, Lausanne, pp 7-25

Wyers GP, Barton M (1989) Polybaric evolution of calc-alkaline magmas from Nisyros, southeastern Hellenic Arc, Greece. J Petrol 30:1-37

Zellmer G, Turner S (2007) Arc dacite genesis pathways: evidence from mafic enclaves and their hosts in Aegean lavas. Lithos 95:346-362

Zouzias D, St Seymour K (2014) Magma mixing and magma mingling episodes throughout the volcanic history of Nisyros volcano, SE extremity of the Aegean Volcanic Arc, as registered by the plagioclase record. J Mineral Geochem (Neues Jahrbuch für Mineralogie-Abhandlungen) 191:189-214 